\title{
Carbonaceous and siliceous Neoproterozoic vase-shaped microfossils (Urucum Formation, Brazil) and the question of early protistan biomineralization
}

\author{
Luana Morais, ${ }^{1}$ Thomas Rich Fairchild, ${ }^{2}$ Daniel J.G. Lahr, ${ }^{3}$ Isaac D. Rudnitzki, ${ }^{4,5}$ J. William Schopf, ${ }^{6,7,8,9}$
} Amanda K. Garcia, ${ }^{6,7}$ Anatoliy B. Kudryavtsev, ${ }^{6,7}$ and Guilherme R. Romero ${ }^{1}$

${ }^{1}$ Graduate program in Geochemistry and Geotectonics, Institute of Geosciences, University of São Paulo. Rua do Lago, 562, Cidade Universitaria, CEP: 05508-080, São Paulo, Brazil 〈lumorasoa@yahoo.com.br〉, 〈graffaeli@gmail.com〉

${ }^{2}$ Department of Sedimentary and Environmental Geology, Institute of Geosciences, University of São Paulo, Rua do Lago, 562, Cidade Universitária, CEP: 05508-080, São Paulo, Brazil 〈trfairch@ @otmail.com〉

${ }^{3}$ Department of Zoology, Institute of Biosciences, University of São Paulo, Rua do Matão, travessa 14, 101, Cidade Universitária, CEP: 05508-090, São Paulo, Brazil 〈dlahr@ib.usp.br〉

${ }^{4}$ Departament of Geophysics, Institute of Astronomy, Geophysics and Atmospheric Sciences, University of São Paulo, Rua do Matão, 1226, CEP: 05508-900 São Paulo, Brazil 〈idrgeo@gmail.com〉

${ }^{5}$ Federal University of Ouro Preto, Department of Geology, Ouro Preto, Rua Diogo de Vasconcelos, 122, Minas Gerais, CEP: 35400-000

${ }^{6}$ Department of Earth, Planetary, and Space Sciences, 595 Charles E. Young Drive East, University of California, Los Angeles, CA 90095 , United States〈schopf@ess.ucla.edu〉,〈agarcia9@ucla.edu〉, 〈kudryavtsev@ess.ucla.edu〉

${ }^{7}$ Center for the Study of Evolution and the Origin of Life, 595 Charles E. Young Drive East, University of California, Los Angeles, CA 90095, United States

${ }^{8}$ Molecular Biology Institute, 495 Hilgard Avenue, University of California, Los Angeles, CA 90095, United States

${ }^{9}$ University of Wisconsin Astrobiology Research Consortium, Department of Geosciences, 1215 W. Dayton St., University of Wisconsin,

Madison, WI 53706, United States

\begin{abstract}
Vase-shaped microfossils (VSMs) occur in dolomitic extraclasts of indeterminate provenance within the basal diamictite of the Neoproterozoic Urucum Formation (Jacadigo Group) of west-central Brazil, having an age constrained between $889 \pm 44 \mathrm{Ma}\left(\mathrm{K}-\mathrm{Ar}\right.$; basement rocks) and $587 \pm 7 \mathrm{Ma}\left({ }^{40} \mathrm{Ar} /{ }^{39} \mathrm{Ar}\right.$ age of early metamorphic cryptomelane in overlying manganese ore). Early isopachous carbonate cement entombed these VSMs, preserving rare direct evidence of original wall composition that is carbonaceous (now kerogenous) in practically all specimens. Some tests are siliceous or composed of a quartz-kerogen mixture; secondary replacement explains some features of these tests, but original biomineralization seems more likely for others. This interpretation, coupled with test morphology, suggests affinity to arcellinid testate amoebae. Five VSM taxa are recognized in the deposit: Cycliocyrillium simplex Porter, Meisterfeld, and Knoll, 2003, and C. torquata Porter, Meisterfeld, and Knoll, 2003, originally described in the Chuar Group (USA), and three new monospecific genera-Palaeoamphora urucumense $\mathrm{n}$. gen. $\mathrm{n}$. sp., Limeta lageniformis $\mathrm{n}$. gen. n. sp., and Taruma rata n. gen. n. sp. Most of the taxonomically important characteristics of these VSMs occur also in extant testate amoebae, but the combinations of some characters, such as organic-walled tests having exceptionally long necks that exhibit terminal apertures (L. lageniformis $\mathrm{n}$. gen. $\mathrm{n}$. sp.), are evidently novel additions to the known diversity of Neoproterozoic VSMs. Evidence of glacially influenced deposition in the conformably overlying Santa Cruz Formation may indicate that the Urucum Formation slightly preceded or was penecontemporaneous with a major Neoproterozoic glaciation, although the VSM-hosting extraclasts must be older, possibly rivaling the age of the testate amoebae of the Chichkan Formation $(766 \pm 7 \mathrm{Ma})$ that are currently regarded as the oldest record of protists in the geological record.
\end{abstract}

\section{Introduction}

Molecular phylogenies and the fossil record indicate that eukaryotic diversification appreciably preceded the early Cambrian appearance of metazoans with hard parts (Knoll, 2014; Butterfield, 2015). Vase-shaped microfossils (VSMs), commonly interpreted to be the oldest evidence of heterotrophic protists in the pre-metazoan fossil record, occur widely in Neoproterozoic rocks younger than $\sim 750 \mathrm{Ma}$. As illustrated in Figure 1, the morphology of these microfossils is similar to such unicellular eukaryotes as chitinozoans, tintinnids, foraminifera, testate amoebae, and acritarchs (Bloeser et al., 1977; Fairchild et al., 1978; Bloeser, 1985; Schopf, 1992; Porter et al., 2003; Bosak et al., 2012). Affinities of VSMs to testate amoebae were first postulated by Schopf (1992, p. 592) and later acknowledged and corroborated by Porter and Knoll (2000, p. 360), an interpretation now generally accepted for most VSMs (e.g., Bosak et al., 2011; Dalton et al., 2013; Strauss et al., 2014). Extant testate amoebae have been 


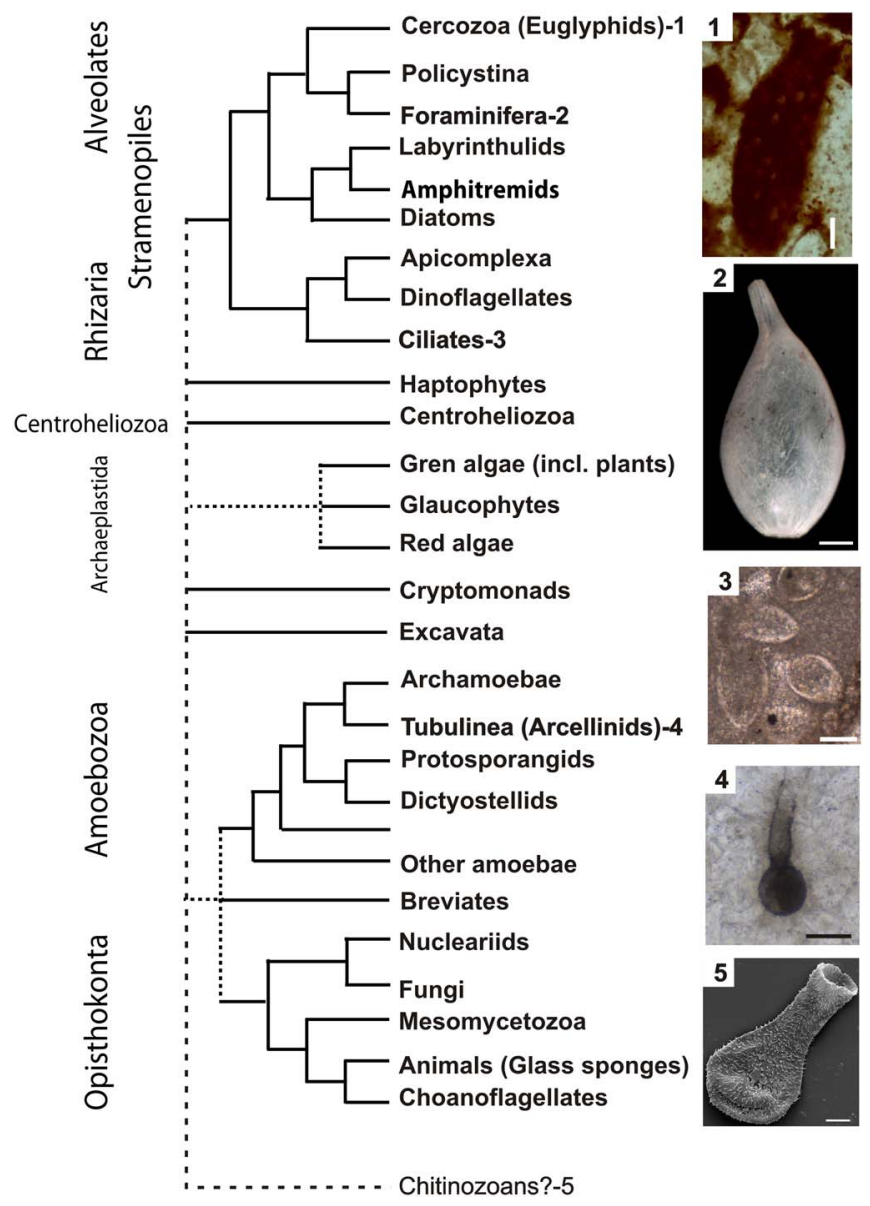

Figure 1. Simplified phylogenetic tree of protists, with examples of selected groups of testate amoebae having a significant fossil record shown on the right. (1) Cercozoa (possible euglyphid from near the top of the Ediacaran Bocaina Formation, Corumbá Group, Serra da Bodoquena, Brazil) (GP/5E 2544); (2) modern foraminiferan (https://depts.washington.edu/forams/order-lagenida/ genus-lagena/); (3) tintinnids from the Jurassic of Mexico (GP/5E-4280), and (4) vase-shaped microfossil interpreted as arcellinid (Tubulinea) (GP/5T-2529 F); (5) chitinozoan, an extinct group of uncertain affinity (https://commons.wikimedia org/wiki/File:Whole_chitinozoan_cropped.jpg). Scale bars $=25 \mu \mathrm{m}$ (1), $50 \mu \mathrm{m}$ (2-4) and $10 \mu \mathrm{m}(\mathbf{5})$.

assigned to two taxonomic groups (Lahr et al., 2015): the Amoebozoa (e.g., arcellinids) and the Rhizaria (e.g., euglyphids and foraminiferans).

The most extensive descriptions of Neoproterozoic VSMs are from carbonaceous cherts, shales, and carbonate nodules in shales of the $\sim 742 \pm 6$ Ma-old Chuar Group of the Grand Canyon, USA (Bloeser, 1985; Karlstom et al., 2000; Porter and Knoll, 2000; Porter et al., 2003). Originally reported as chitinozoans (Bloeser et al., 1977), the Chuar VSMs are currently regarded as among the oldest fossil evidence not only of testate amoebae (Schopf, 1992, p. 588, 592; Parfrey et al., 2011; Fiz-Palacios et al., 2014), but of protists in general (Knoll, 2014; Butterfield, 2015) and of eukaryvory (Porter et al., 2003; Porter, 2011; Knoll, 2014; Strauss et al., 2014). Elaborating on the reported occurrences of VSMs listed by Porter and Knoll (2000), Strauss et al. (2014) tabulated the presence of vasiform microfossils, sensu lato, from more than two dozen Neoproterozoic units worldwide, part of which are illustrated in Figure 2. Of particular interest here are assemblages sharing species in common with the Chuar Group,
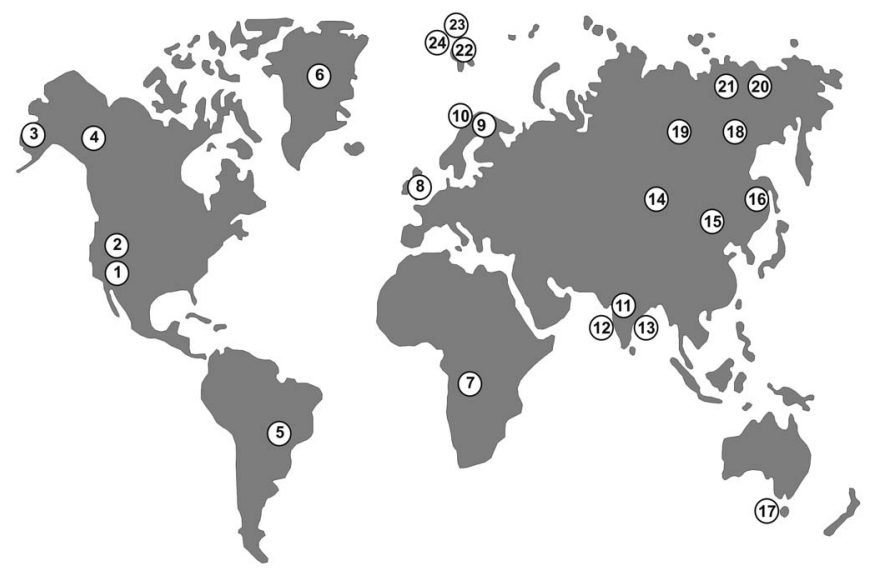

1. USA- Chuar Gr. (770-716 Ma)

2. USA- Uinta Mountain Gr. (785-716 Ma)

3. USA- Tindir Gr. (811-716 Ma)

4. Canada- Callison Lake Dolostone $(740 \mathrm{Ma})$

5. Brazil- Urucum Fm. (889-587 Ma)

6. Greenland- Eleonore Bay Gr. (780-716 Ma)

7. Namibia- Rasthof Fm. (665-635 Ma)

8. Scotland- Bonahaven Fm. (665-635 Ma)

9. Sweden- Visingso Beds (805-663 Ma)

10. Norway- Tanafjorden Gr. (807-716 Ma)

11. India- Simla Slates (823-716 Ma)

12. India- Vaishnodevi Limestone (<950 Ma)

13. India- Vindhyan Supergr. (>650 Ma) 14. China- Dengying Fm. (551-542 Ma) 15. China- Doushantuo Fm. (635-551 Ma) 16. China- Huaibei Gr. (1000-850 Ma) 17. Tasmania- Togari Gr. (780-716 Ma) 18. Mongolia- Tsagaan Oloom Fm. (800-766 Ma) 19. Kazakhstan- Chichkan Fm. $(665-635 \mathrm{Ma})$ 20. Russia- Chatkaragai Suite $(800-766 \mathrm{Ma})$ 21. Russia- Upper Min'yar Fm. (820-687 Ma) 22. Svalbard-Backlundtoppen Fm. (780-716 Ma) 23. Svalbard- Draken Fm. (780-716 Ma) 23. Svalbard- Draken Fm. $(780-716 \mathrm{Ma})$
24. Svalbard- Elbobreen Fm. (780-716 Ma)

Figure 2. Geographic distribution of reported Neoproterozoic vasiform microfossils. References: Backlundtoppen Group-Svalbard (Knoll and Calder, 1983); Simla Slates-India (Nautiyal, 1978); Bonahaven FormationScotland (Anderson et al., 2013); Callison Lake Dolostone- Canada (Strauss et al., 2014); Chatkaragai Suite-Russia (Sergeev and Schopf, 2010); Chichkan Formation-Kazakhstan (Sergeev and Schopf, 2010); Chuar Group —USA (Porter et al., 2003); Dengying Formation (Ding et al., 1992; Duan et al., 1993; Zhang, 1994); Doushantuo Formation-China (Duan, 1985; Duan et al., 1993; Li et al., 2008); Draken Formation-Svalbard (Knoll et al., 1991); Elbobreen Formation-Svalbard (Knoll and Calder, 1983); Eleonore Bay Group-Greenland (Vidal, 1979; Green et al., 1988); Huaibei Group-China (Xiao et al., 2014); Rasthof Formation-Namibia (Bosak et al., 2011); Tanafjorden Group-Norway (Vidal and Siedlecka, 1983; Vidal and Moczydłowska, 1995); Togari Group-Tasmania (Saito et al., 1988; Turner et al., 1998); Tsagaan Oloom Formation-Mongolia (Bosak et al., 2011); Tindir Group-USA (Allison and Awramik, 1989; Macdonald et al., 2010); Upper Min'yar Formation-Russia (Maslov et al., 1994; Maslov, 2004); Uinta Mountain Group-USA (Dehler et al., 2010); Urucum Formation-Brazil (this paper); Vaishnodevi Limestone and Vindhyan Group-India (Maithy and Babu, 1988; Venkatachala and Kumar, 1998); and Visingsö Beds-Sweden (Knoll and Vidal, 1980).

known from the United States (Pahrump Group, Horodyski, 1993; Corsetti et al., 2003; Uinta Mountain Group, Dehler et al., 2010), Canada (Callison Lake Dolostone, Strauss et al., 2014), Svalbard (Elbobreen Formation, Knoll and Calder, 1983; Backlundtoppen Formation, Knoll et al., 1989; Draken Formation, Knoll et al., 1991), and, with this and a previous report, Brazil (Urucum Formation, Fairchild et al., 1978; this paper). Other occurrences that are broadly similar but contain distinct taxa or taxa requiring further systematic study are known from Greenland (Eleonore Bay Group, Vidal, 1979; Green et al., 1988), Saudi Arabia (Jabal Rockham, Binda and Bokhari, 1980), Sweden (Visingsö Group, Ewetz, 1933; Knoll and Vidal, 1980; Vidal and Siedlecka, 1983; Martí Mus and Moczydłowska, 2000), China (Doushantuo Formation, Duan, 1985; Duan et al., 1993; Li et al., 2008; Dengying Formation, Zhang and Li, 1991; Ding et al., 1992; Duan et al., 1993; Zhang, 1994; Huaibei Group, Xiao et al., 2014), Kazakhstan (Chichkan Formation, Sergeev and Schopf, 2010), Russia (Chatkaragai Suite, Sergeev and Schopf, 2010), and Tasmania (Togari Group, Saito et al., 1988; Turner et al., 1998). Vasiform microfossils having distinctly differing morphology, 
insufficient illustrations, and/or poor preservation have been reported from Alaska (USA, Tindir Group, Allison and Awramik, 1989; Macdonald et al., 2010), Mongolia (Tsagaan Oloom Formation, Bosak et al., 2011), Namibia (Rasthof Formation, Bosak et al., 2011), Scotland (Bonahaven Formation, Anderson et al., 2013), Norway (Tanafjorden Formation, Vidal and Siedlecka, 1983; Vidal and Moczydłowska, 1995), India (Simla Slates, Nautiyal, 1978; Vindhyan Group, Maithy and Babu, 1988; Vaishnodevi Limestone, Venkatachala and Kumar, 1998), and Russia (Upper Min'yar Formation, Maslov et al., 1994; Maslov, 2004).

Taken together, these numerous reports establish that considerable diversification occurred among testate protists prior to the end of the Precambrian (Fiz-Palacios et al., 2014; Lahr et al., 2015).

The present study analyzes VSMs first reported by Fairchild et al. (1978) from carbonate clasts in diamictite near the base of the Neoproterozoic Urucum Formation (Jacadigo Group, Brazil). To extend this work, we have here used, in addition to standard petrographic microscopy and scanning electron microscopy (SEM), two techniques recently introduced in studies of three-dimensionally well-preserved permineralized microfossils: confocal laser scanning microscopy (CLSM; Martí Mus and Moczydłowska, 2000; Schopf et al., 2006, 2016) and Raman spectroscopy (Schopf et al., 2002, 2016). We show that the Urucum VSMs include two species previously described from the Chuar Group (Porter et al., 2003) as well as others that are sufficiently distinct to warrant erection of three new monospecific genera, one of which is identifiable in figures of previously unnamed specimens from the Chuar Group. Additionally, we record an unnamed form of VSMs that consists of paired tests (Porter et al., 2003, p. 410, fig. 2.1), which we here refer to as "doublets," that resemble products of asexual binary fission in modern testate amoebae. In addition to adding to the known diversity of Neoproterozoic protistans, the Urucum VSMs are exceptional in comparison with practically all other reported VSMs in their preservation of direct evidence of original wall composition, which in the great majority of the tests is carbonaceous (kerogenous). Some walls, however, are composed partially or entirely of silica, the origin and significance of which are discussed below.

\section{Geological setting}

The VSMs here reported occur in dolostone clasts within a diamictite near the base of the Urucum Formation in the Neoproterozoic Jacadigo Group of the Urucum massif in the southern Paraguay Fold Belt of west-central Brazil (Fig. 3; Fairchild et al., 1978; Freitas et al., 2011). The Jacadigo Group lies unconformably upon crystalline basement at the junction of the Rio Apa block with the Amazon craton and is composed of two units (Almeida, 1964) (Fig. 3): the $280 \mathrm{~m}$ thick Urucum Formation, consisting of coarse-grained arkoses (including diamictites), conglomerates and breccias, coarse- to mediumgrained sandstones and subordinate siltstones and carbonates, having bedded manganese ore close to its top; and the conformably overlying Santa Cruz Formation, for a few tens of meters near its base composed of a granular iron-formation and varied siliciclastic deposits overlain by $300 \mathrm{~m}$ of banded hematite-rich iron-formation intercalated with immature siliciclastic layers that include at least three beds of diamictite (Dorr, 1945; Almeida, 1964; Angerer et al., 2016).

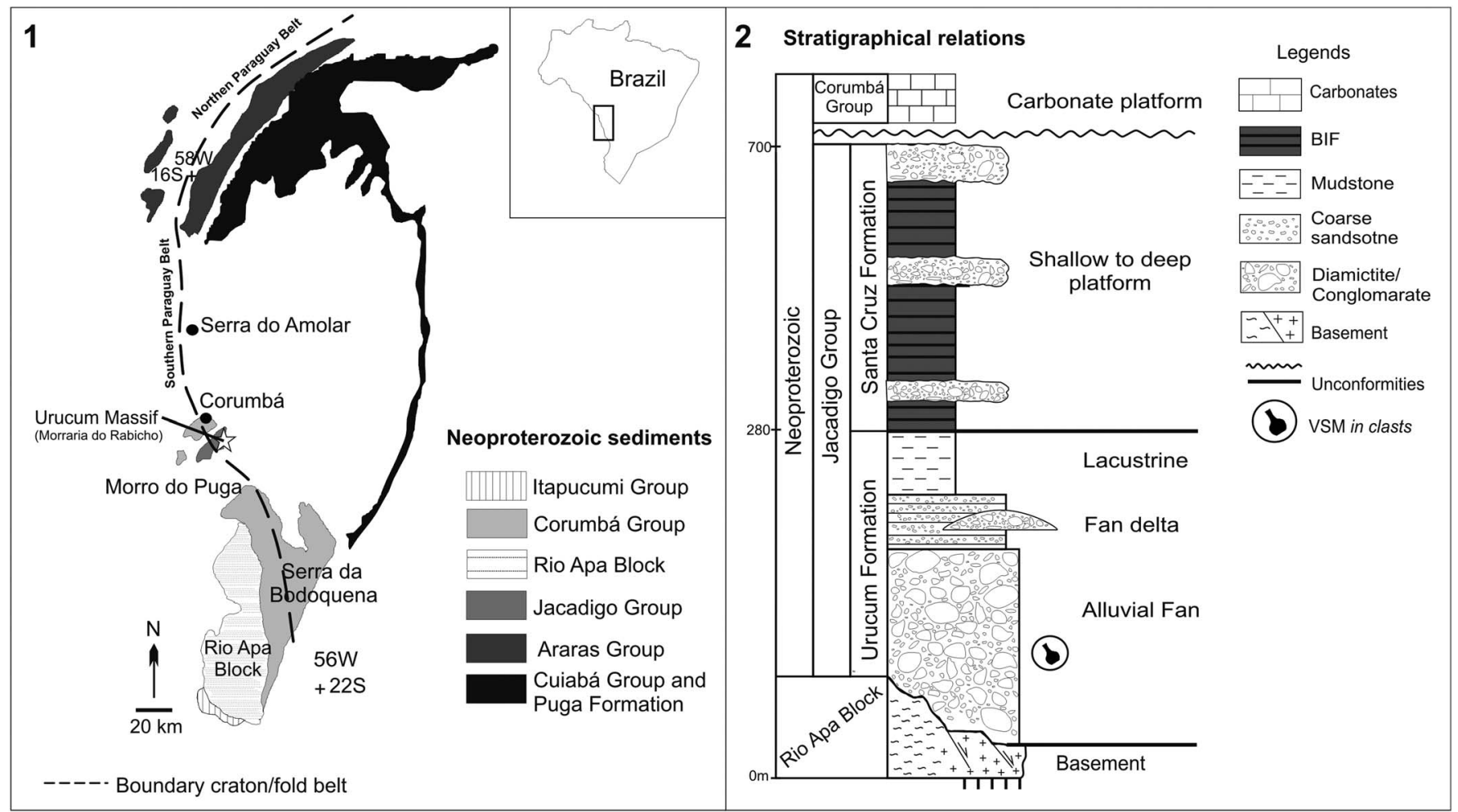

Figure 3. Geologic setting of study area. (1) Simplified geological map of the southern Paraguay Fold Belt and (2) schematic stratigraphic column of Jacadigo Group (modified from Freitas et al., 2011); white star in part 1 indicates the approximate location of the fossiliferous locality at the northern end of Morraria do Rabicho. 
A glacial influence upon sedimentation of the Jacadigo Group in the study area near Corumbá has been proposed on the basis of lonestones, diamictites, and recently discovered distinctive $\delta^{13} \mathrm{C}$ and $\delta^{57} \mathrm{Fe}$ signatures (Angerer et al., 2016) associated with the iron deposits in the Santa Cruz Formation in the upper part of the group (Barbosa, 1949; Dorr, 1973; Leeuwen and Graf, 1987; Urban et al., 1992). At Morro do Puga (Fig. 3), $\sim 70 \mathrm{~km}$ south of the fossiliferous unit studied here, diamictites and a pink cap-carbonate, within the type-section of the Puga Formation (Maciel, 1959), have likewise been interpreted in light of one of the late Neoproterozoic 'Snowball Earth' glacial scenarios (Hoffman et al., 1998; Boggiani and Coimbra, 2002; Hoffman and Schrag, 2002; Babinski et al., 2013). Stratigraphic relationships between this formation and the Jacadigo Group are not clear, however. Freitas et al. (2011) interpreted sedimentation in the Group to reflect continental rifting rather than global glaciation. Moreover, they identified a succession of alluvial fan, siliciclastic lacustrine, fan-delta, and bedload-dominated fluvial depositional systems within the Urucum Formation, conformably underlying the Santa Cruz Formation, that are difficult to relate directly to a glacial paleoenvironment. Based on a proposal by Leeuwen and Graf (1987), these apparently opposing views may be reconciled if deposition of the Urucum-Santa Cruz sequence began just prior to or penecontemporaneously with one of the three major Neoproterozoic glaciations - the Sturtian ( 716 Ma), Marinoan $(\sim 635 \mathrm{Ma})$, or Gaskiers ( $\sim 580 \mathrm{Ma})$ (ages according to Cohen et al., 2013).

Despite the broad constraints on age of the Jacadigo Group, available data does allow some insight into possible temporal relationships with the Neoproterozoic glaciations. The Jacadigo Group is demonstrably younger than its underlying granitic basement, dated at $\sim 889 \pm 44$ Ma by K-Ar (K-feldspar from granite; Hasui and Almeida, 1970), and is evidently older than $\sim 587 \pm 7 \mathrm{Ma}$, which is the minimum depositional age based on ${ }^{40} \mathrm{Ar} /{ }^{39} \mathrm{Ar}$ dating of the late diagenetic or early metamorphic crystallization of cryptomelane in the manganese ore near the top of the formation (Piacentini et al., 2013). The Jacadigo Group may be younger than $\sim 623 \pm 15 \mathrm{Ma}$ (O'Connor and Walde, 1985), based on the K-Ar age of a single sample of poorly exposed quartz porphyry of the La Pimienta Formation that cuts the basement underlying the Bolivian equivalent of the Jacadigo Group (Litherland and Bloomfield, 1981; Litherland et al., 1986). This value and the stratigraphic relationships of the Bolivian quartz porphyry require corroboration. If it could be proved that glacial activity during deposition of the Santa Cruz Formation overlying the Urucum Formation was penecontemporaneous with sedimentation of the Puga Formation at Morro do Puga and in the Serra da Bodoquena, $200 \mathrm{~km}$ to the southeast from the site here studied (Walde and Oliveira, 1980; Boggiani, 2010), then the age of $706 \pm 9 \mathrm{Ma}$ (U-Pb, SHRIMP) obtained by Babinski et al. (2013) for the youngest detrital zircon grain in the Puga Formation would also be relevant to that of the Jacadigo Group. Corroboration of this suggestion would require additional data supporting both the correlation between the Puga and Santa Cruz formations and the interpretation that the glaciation affecting the two formations was related to a global rather than a local event. Were such strictures to be substantiated, the age of deposition of the Jacadigo Group would be constrained to the interval from $\sim 590 \mathrm{Ma}$ to $\sim 706 \mathrm{Ma}$, suggesting the Marinoan and Sturtian events rather than the Gaskiers as candidates for the Puga-Santa Cruz glaciation.

The VSMs described here are not necessarily coeval with any of these glaciations. They occur in clasts of unknown provenance-like the youngest detrital grains of zircon in the Puga Formation (Babinski et al., 2013) — and may come from an eroded pre-Urucum source that is appreciably older than the Puga Formation 706 Ma-old detrital zircon. Thus, they are possibly older than the 740-750 Ma-old VSMs of the Chuar and Yukon groups of North America (Porter et al., 2003; Strauss et al., 2014) and the 770 Ma-old VSMs of the Chichkan Formation of Kazakhstan (Sergeev and Schopf, 2010).

\section{Materials and methods}

VSMs in the Urucum Formation were originally reported from dolostone clasts from diamictite near the base of the formation at the northern end of the Morraria do Rabicho collected by Zaine (1991) and from an arkosic breccia near the top of the formation at Morro do Urucum (Fig. 3) collected by Barbour (Fairchild et al., 1978, p. 77, pl. 1, figs. 7-9). The latter outcrop, however, has not been re-located and VSMs have not been discovered in any other arkosic or carbonate beds within the formation. Similarly, nowhere else in the Corumbá region have we found VSMs in other dolostone-bearing units, such as the Bocaina Formation, nor in cap dolostones at the type locality of the Puga Formation at Morro do Puga (Fig. 3; Boggiani et al., 2003; Babinski et al., 2013). Rare, morphologically markedly different VSMs, currently under study by L.M., occur in the Serra da Bodoquena region, preserved in a younger phosphorite of the Corumbá Group.

In summary, the source of the Urucum VSM-bearing clasts is presently unknown and apparently located outside the depositional basin of the Jacadigo Group, which is an interpretation that justifies their description as extraclasts.

The VSM-bearing dolostone extraclasts were collected at three localities, including that of Zaine (1991), within a single extensive outcrop of diamictite near the base of the Urucum Formation at the northern end of Morraria do Rabicho, in the channel leading from the Paraguai River to the Lagoa Negra (locality 1: $19^{\circ} 1^{\prime} 49.98^{\prime \prime S}, 57^{\circ} 28^{\prime} 11.94^{\prime \prime W}$; locality $2: 19^{\circ} 1^{\prime} 52.61 " \mathrm{~S}$, $57^{\circ} 28^{\prime} 15.16^{\prime \prime}$; locality 3: $\left.19^{\circ} 11^{\prime} 53.20^{\prime \prime} \mathrm{S}, 57^{\circ} 28^{\prime} 15.64^{\prime \prime} \mathrm{W}\right)$. VSMs were also studied in four dolostone clasts reportedly collected near the top of the formation at Morro do Urucum, all localities occurring near Corumbá, Mato Grosso do Sul, west-central Brazil (Fig. 3; Fairchild et al., 1978).

The following morphological characters regarded as significant by Porter et al. (2003) are used here to describe the Urucum VSMs: body shape, total length (L) and width (W), aperture diameter (AD), neck length (NL), wall thickness (WT) and uniformity, and test composition. Aspect ratios (L/W) provide an estimate of the sphericity of the tests and are helpful in defining body shape. For tests that exhibit long straight or flared necks (Limeta lageniformis $\mathrm{n}$. gen. n. sp. and Palaeoamphora urucumense $\mathrm{n}$. gen. $\mathrm{n}$. sp., respectively), the aspect ratio was calculated as BL/W, in which BL is "body length" defined as the total test length (L) minus the neck length $(\mathrm{NL})$. In the taxonomic 
descriptions, below, mathematical averages are indicated by $x$ and their standard deviation by $\sigma$.

At the Instituto de Geociências, Universidade de São Paulo (IGc-USP), the clast-hosted VSMs were studied in $\sim 50 \mu \mathrm{m}$ thick petrographic thin sections using a Leica DM 750 P microscope equipped with a Leica MC $170 \mathrm{HD}$ camera. Some images were obtained using a simplified version of the "white-card" technique of Folk (1987), by placing a small piece of white paper beneath the thin section to diffuse the incoming light beam, thereby softening the visual effect of carbonate crystal boundaries and permitting a clearer view of individual rock components, especially of associated organic matter. Transmitted white light and plane-polarized light optical images of thin section-embedded specimens were also acquired at the University of California, Los Angeles (UCLA) using fluorescence-free microscopy immersion oil and a Leitz Orthoplan 2 microscope equipped with a Nikon DS Microscope Digital Camera.

Confocal laser scanning micrographs were obtained at UCLA using an Olympus Fluoview 300 confocal laser scanning biological microscope system equipped with two Melles Griot lasers, a $488 \mathrm{~nm} 20 \mathrm{~mW}$-output argon ion laser and a $633 \mathrm{~nm}$ $10 \mathrm{~mW}$-output helium-neon laser. Images were acquired using a 100x oil-immersion objective, fluorescence-free microscopy immersion oil, and filters in the light-path to remove wavelengths $<510 \mathrm{~nm}$ (for $488 \mathrm{~nm}$ laser excitation) and $<660 \mathrm{~nm}$ (for $633 \mathrm{~nm}$ laser excitation) from the laser-induced fluorescence emitted by the specimens. Image-sets were subsequently processed using the VolView v3.4 3D-rendering computer program that permits image manipulation in three dimensions.

Raman molecular-structural compositional analyses of the fossils and associated minerals were carried out at UCLA using a T64000 triple-stage confocal laser-Raman system that permits acquisition both of point spectra and of Raman images that display the two-dimensional spatial distribution of the molecularstructural components of the specimens and their associated minerals. A Coherent Innova argon ion laser provided excitation at $457.9 \mathrm{~nm}$ permitting data to be obtained over a range from $\sim 300$ to $\sim 3000 \mathrm{~cm}^{-1}$ using a single spectral window centered at $1800 \mathrm{~cm}^{-1}$. The laser power used was $\sim 6-8 \mathrm{~mW}$ over a $\sim 1 \mu \mathrm{m}$ spot, a configuration well below the threshold for radiation damage in kerogenous fossils, and the thin sections were covered by a veneer of fluorescence-free microscopy immersion oil, the presence of which has been shown to have no discernible effect on the Raman spectra acquired (Schopf et al., 2005). Varying pixel intensities in the two-dimensional Raman images, acquired at the $\sim 463 \mathrm{~cm}^{-1}$ band of quartz and the $\sim 1600 \mathrm{~cm}^{-1}$ " $\mathrm{G}$ " band of kerogen, correspond to the relative concentrations of the material analyzed.

Repositories and institutional abbreviations.-The petrographic thin sections analyzed here are designated by the prefix GP/5T, which is reserved for type and other published specimens belonging to the Micropaleontology Collection deposited in the Laboratório de Paleontologia Sistemática (LPS) of the Instituto de Geociências, Universidade de São Paulo, Brazil. Thin section GP/ L-3E-46, illustrated in Fairchild et al. (1978, p. 77, pl. 1, figs. 7-9), is deposited in the Paleobotany Collection (GP/3) in the LPS. The location of illustrated microfossils is indicated by the number of the thin section in which it occurs and a location indicated by a letter (A, B, C, etc.) on maps of the thin sections deposited in the LPS. The designation HUPC for type specimens described by Porter et al. (2003) refers to the Harvard University Paleobotanical Collections.

\section{Preservational and paleoenvironmental considerations}

The VSM-bearing clasts are predominantly dolomitic, containing small amounts of detrital quartz or other minerals and minor authigenic quartz (Fig. 6.11, 6.13). Dolomite having a fibrous to bladed habit forms a distinct rim around nearly all Urucum VSMs (Figs. 4, 5.1, 5.3, 5.6, 6.1). In such rims, the narrow $(<10 \mu \mathrm{m}$ thick) layer closest to the wall represents early diagenetic isopachous calcite or aragonite cement that later recrystallized and later replaced by sparry dolomite while nevertheless conserving a palimpsest of the fibrous habit of the original carbonate (Figs. 4.1, 4.2, 4.4, 5.1, 5.3, 5.6, 6.1-6.9, 6.14-6.16). Such cement also coats the interiors of some tests or has completely filled them (Figs. 4.2, 6.2). More commonly, however, the tests are filled by mosaic sparry dolomite like that of their encompassing matrix. A significant difference between the Urucum VSMs and practically all such specimens previously described is that they preserve their original wall thicknesses and, importantly, evidence of their original wall composition. The great majority is carbonaceous (kerogenous) (e.g., Fig. 6.1, 6.4-6.9, 6.14), but some exhibit entirely siliceous or mixed kerogenous-siliceous walls, as documented by Raman imagery and optical petrography (Figs. 5.7, $5.8,6.2,6.3,6.7,6.10,6.11)$. Not only have the VSMs retained their walls, but the original shapes of their tests are

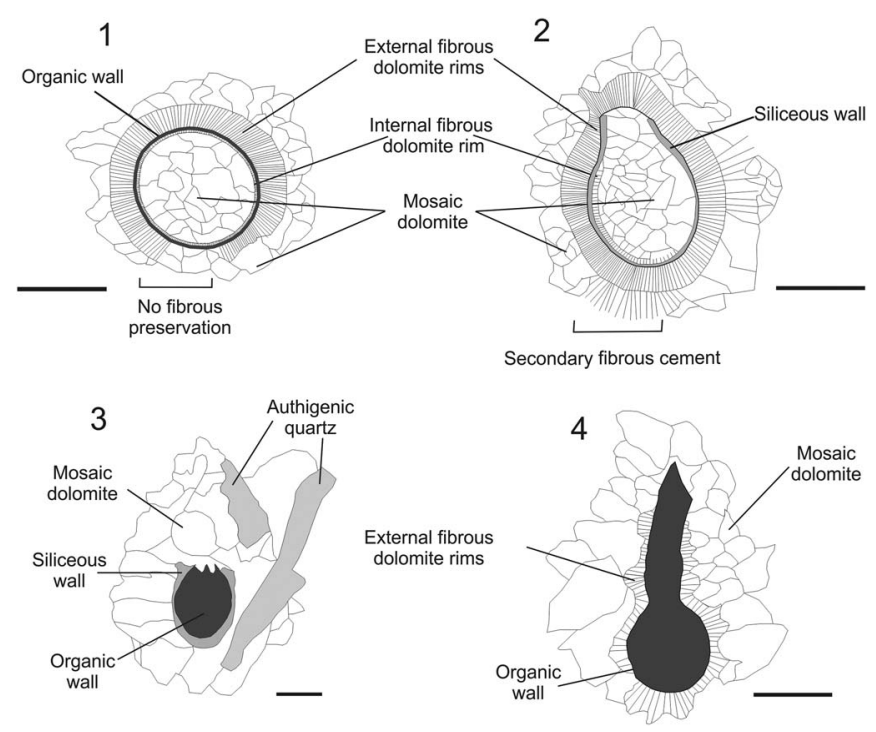

Figure 4. Schematic representation of textural relationships of VSMs and matrix in dolostone clasts in diamictite of the Neoproterozoic Urucum Formation (Jacadigo Group, Corumbá, Brazil) showing tests of VSMs exhibiting external $(\mathbf{1}, \mathbf{2}, \mathbf{4})$ and partial internal (2) fibrous to bladed palimpsest carbonate cement textures and matrices dominated by mosaic dolospar. (1) Transverse section of the organic test of an indeterminate VSM; (2) longitudinal section through siliceous test of Cycliocyrillium torquata Porter, Meisterfeld, and Knoll, 2003 (Fig. 6.2, 6.3); (3) longitudinal section through the siliceous test of the holotype of Taruma rata $\mathrm{n}$. gen. n. sp. illustrated in Figure $6.10,6.11 ;(\mathbf{4})$ longitudinal section through organic test of the holotype of Limeta lageniformis n. gen. n. sp. (GP/5T-2529 F) illustrated in Figure 6.9. Scale bars $=50 \mu \mathrm{m}$. 

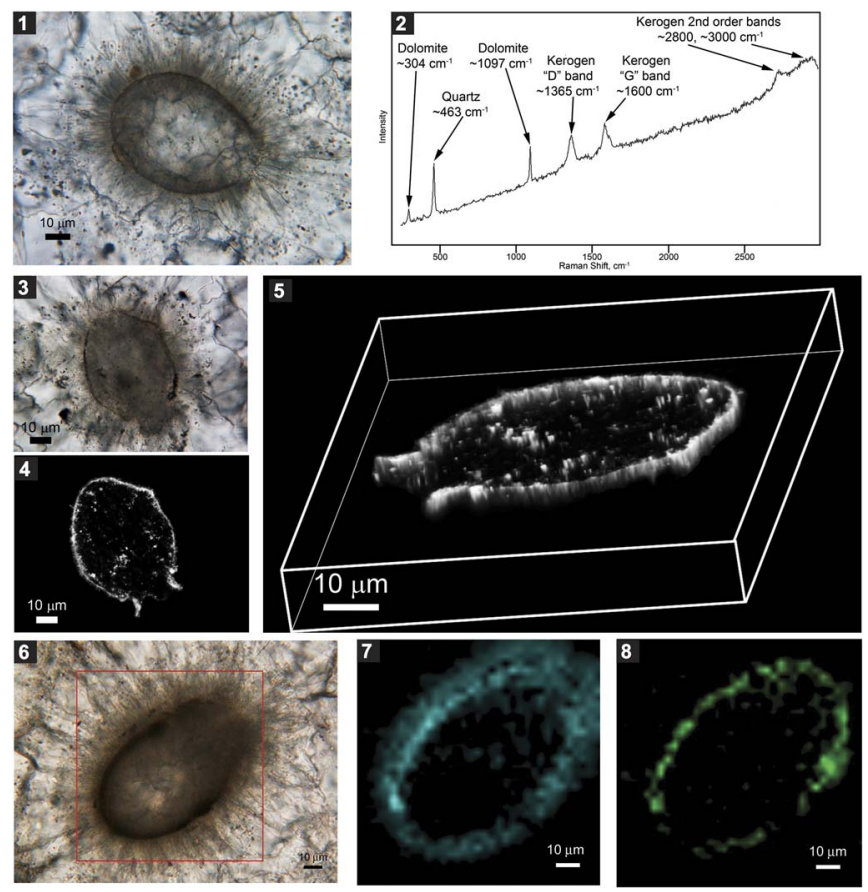

Figure 5. Optical, CLSM, Raman images, and a Raman spectrum of thin section-embedded VSMs from dolostone clasts in diamictite of the Neoproterozoic Urucum Formation (Jacadigo Group, Corumbá, Brazil). (1) Optical image of organic test of Cycliocyrillium simplex Porter, Meisterfeld, and Knoll, 2003 (GP/5T-2537 A); (2) Raman spectrum of test shown in (1), indicating the principal bands of the embedding dolomite and quartz and the "D," "G," and second-order carbonaceous kerogen bands of its test; (3-5) optical $(\mathbf{3})$ and CLSM images $(4, \mathbf{5})$ of Palaeoamphora urucumense n. gen. n. sp. that exhibits a constricted short neck subtending its aperture (GP/5T-2537 B); (6-8) optical image (6) and corresponding Raman images $(7,8)$ of a test attributed to $C$. simplex $(\mathrm{GP} / 5 \mathrm{~T}-2537 \mathrm{C})$ showing a close association between kerogen (7) and silica (8).

preserved as well, despite the post-depositional recrystallization and dolomitization that has altered much of the primary rock fabric. We conclude that the very early isopachous carbonate cement was fundamental in preserving the walls of the Urucum VSMs (Figs. 4, 5, 6).

Attempts were unsuccessful to identify the source of the VSM-bearing clasts among carbonate intraclasts present in the continental debris flow-dominated alluvial fan facies of the Urucum Formation (Freitas et al., 2011), all such intraclasts proving to be nonfossiliferous and calcitic rather than dolomitic. Indeed, the isopachous cement encasing the VSMs documented here is much more characteristically marine (Tucker and Wright, 1990) than continental. Such a marine origin for the Urucum VSMs is also consistent with the paleoenvironment inferred for practically all other occurrences of VSMs (e.g., Porter and Knoll, 2000). Available evidence thus indicates that the VSM-bearing clasts should be regarded as extraclasts of unknown provenance apparently derived from pre-Urucum marine rocks.

\section{Systematic paleontology}

Of the approximately 3,000 specimens of VSMs detected in clasts from the Urucum Formation, 55 specimens having longitudinal sections oriented parallel to the thin section surface were examined in detail and differentiated into five species and an unnamed form of paired tests here referred to as "doublets." Two of the five taxa, Cycliocyrillium simplex and C. torquata, were originally described by Porter et al. (2003), and the other three are here assigned to new genera and species: Paleoamphora urucumense n. gen. n. sp., Limeta lageniformis n. gen. n. sp., and Taruma rata $\mathrm{n}$. gen. $\mathrm{n}$. sp.

Vase-shaped Microfossils

Genus Cycliocyrillium Porter, Meisterfeld, and Knoll, 2003

Type species.-Cycliocyrillium simplex Porter et al., 2003.

Other species._Cycliocyrillium torquata Porter et al., 2003.

Diagnosis.-Bulbous to pyriform VSMs having a circular aperture either flush with the test or associated with a narrow collar or short uncurved neck, not exceeding one-tenth the total length of the specimen; angle between the apertural plane and the aboral axis $\sim 90^{\circ}$.

Remarks.-As originally described by Porter et al. (2003, p. 415), the presence of an uncurved neck is a diagnostic feature for the genus Cycliocyrillium, but the neck is absent in the type species $C$. simplex. Therefore, we have emended the generic and specific diagnoses to allow for the lack of a neck or collar in the genus and to differentiate clearly between $C$. simplex, which has no collar or neck, and $C$. torquata, which does.

The dimensions of the specimens of Cycliocyrillium in the Urucum Formation are similar to those of the type material presented by Porter et al. (2003) from the Neoproterozoic Chuar Group. Unlike the type material, which is preserved as molds, siliceous casts, and carbonate substitutions, the specimens described here exhibit walls of varied composition. Nearly all are carbonaceous (kerogenous) (Figs. 4.1, 6.1), which we interpret as indicating an originally organic wall. A few are siliceous (Fig. 6.2, 6.3) or a carbonaceous-siliceous mixture (Fig. 4.6-4.8). Their possible origins are discussed in the next section.

Cycliocyrillium simplex Porter, Meisterfeld, and Knoll, 2003 Figures 5.1, 5.6, 6.1

2003

Cycliocyrillium simplex Porter et al., p. 415, fig. 6.1-6.9.

Holotype.-HUPC\# 64455, upper Tonian ( 742 \pm 6 Ma), Kwagunt Formation, Chuar Group, Arizona.

Materials.-N = 24; GP/5T: 2529 B, C, D, E, I; 2531 A, B, D, E; 2532 B, H; 2534 A, C, E; 2535 A; 2536 F, I, L; GP/5T: 2539 B, C, E, F; 2541 A, C.

Diagnosis.-Specimens of Cycliocyrillium with smooth apertural margin flush with the rest of the test.

Description.-Specimens from the Urucum Formation have pyriform tests $(\mathrm{L}=50-139 \mu \mathrm{m}, \quad x=87 \mu \mathrm{m}, \quad \sigma=20 \mu \mathrm{m}$; $\mathrm{W}=42-96 \mu \mathrm{m}, x=62 \mu \mathrm{m}, \sigma=14 \mu \mathrm{m})$, and exhibit a circular aperture (aperture diameter, $\mathrm{AD}=11-22 \mu \mathrm{m}, x=22 \mu \mathrm{m}$, $\sigma=6 \mu \mathrm{m}$ ) without a collar or neck. Aspect ratios (L/W) range 

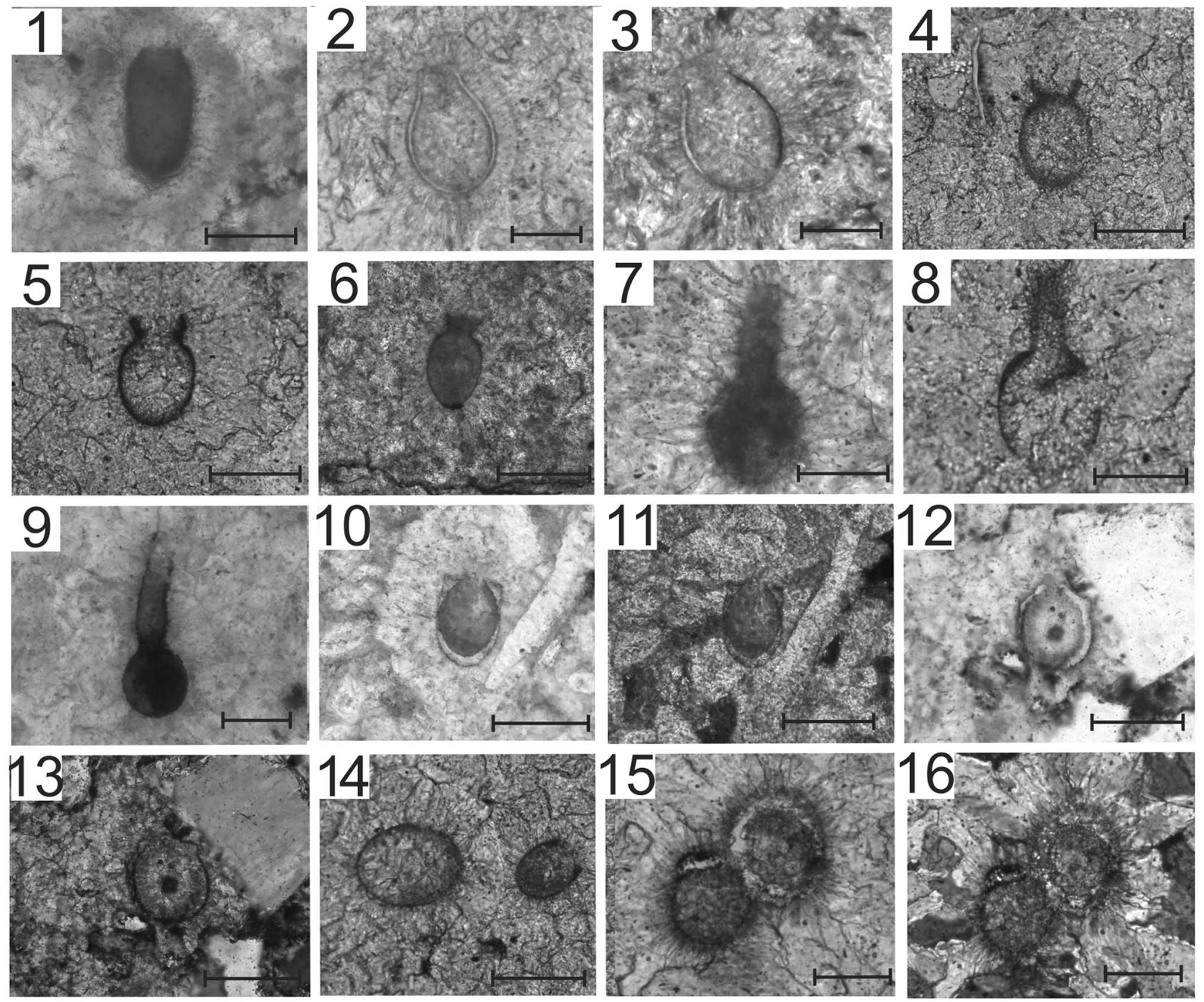

Figure 6. Photomicrographs of petrographic thin sections containing VSMs from the Neoproterozoic Urucum Formation (Jacadigo Group, Corumbá, Brazil), including specimens attributed to taxa first described by Porter et al. (2003) from the Chuar Group (Grand Canyon, Arizona, USA) (1-3) three new monospecific genera $(\mathbf{4 - 1 3})$ and an unnamed form of paired tests $(\mathbf{1 5}, \mathbf{1 6})$ : (1) carbonaceous test of Cycliocyrillium simplex Porter, Meisterfeld, and Knoll, 2003, enclosed by fibrous cement (GP/5T-2537 D); (2) siliceous-walled specimen of Cycliocyrillium torquata Porter, Meisterfeld, and Knoll, 2003, exhibiting a short neck and evidence of an originally fibrous isopachous cement covering both the interior and exterior wall surfaces (GP/5T-2532 G); (3) same specimen under crossed nicols; $(\mathbf{4}, \mathbf{5})$ paratypes of Palaeoamphora urucumense n. gen. n. sp. exhibiting characteristic funnel-like neck and organic wall (GP/5T-2536 A and B, respectively); (6) holotype of Palaeoamphora urucumense n. gen. n. sp. (GP/5T-2534 F); (7) paratype of Limeta lageniformis $\mathrm{n}$. gen. n. sp. (GP/5T-2530 A); (8) paratype of Limeta lageniformis n. gen. n. sp. (GP/5T-2529 F), viewed using the white card technique (see text); (9) holotype of Limeta lageniformis n. gen. n. sp. (GP/5T-2536 C); (10, 11) robust siliceous-walled holotype of Taruma rata $\mathrm{n}$. gen. $\mathrm{n}$. sp. with ellipsoidal internal chamber lined by organic matter (GP/5T-2533 B), viewed using white card technique (see text); (11) same specimen under crossed nicols; secondary quartz partially replaces the carbonate beside the test; $(\mathbf{1 2}, \mathbf{1 3})$ siliceous-walled paratype of Taruma rata $\mathrm{n}$. gen. $\mathrm{n}$. sp., exhibiting a roof-like apertural region and an internal palimpsest of fibrous isopachous cement (GP/5T-2545); note secondary quartz beside test; (13) same specimen under crossed nicols; (14) carbonaceous-walled test attributed to Taruma rata with reservations $(\mathrm{GP} / 5 \mathrm{~T}-2536 \mathrm{D})$. $(\mathbf{1 5}, \mathbf{1 6})$ Unnamed form comprising a doublet of adpressed tests of unequal size $(\mathrm{GP} / 5 \mathrm{~T}-2530 \mathrm{~B})$; quartz partially fills one test and cuts the other; (16) specimen under crossed nicols. Scale bars $=100 \mu \mathrm{m}$ for $(\mathbf{1}, \mathbf{4 - 6}, \mathbf{8 - 1 3})$ and $50 \mu \mathrm{m}$ for $(\mathbf{2}, \mathbf{3}, \mathbf{7}, \mathbf{1 4 - 1 6})$.

from 1 to 1.8 ( $x=1.4 ; \sigma=0.3)$. Walls organic and uniformly thick (WT $=3-6 \mu \mathrm{m}, x=4.3 \mu \mathrm{m}, \sigma=1.1 \mu \mathrm{m}$ ).

Remarks.-Raman confocal spectroscopy identified silica as well as kerogen within the wall of the specimen illustrated in Figure 5.6-5.8, which raises questions addressed in the next section regarding possible biomineralization in early testate amoebae.
Cycliocyrillium torquata Porter, Meisterfeld, and Knoll, 2003

Figure 6.2, 6.3

2003 Cycliocyrillium torquata Porter, Meisterfeld, and Knoll, p. 415, figs. 6.11-6.23, 18.1 .

2014 Cycliocyrillium torquata Porter et al.; Strauss et al., p. 660 , fig. $2 \mathrm{~F}$. 
Holotype.-HUPC\# 64453, upper Tonian ( 742 \pm 6 Ma), Kwagunt Formation, Chuar Group, Arizona.

Material.-N = 10; GP/5T 2529 G, H, J, K; 2531 C; 2532 A, C, D, F, G.

Diagnosis.- Specimens of the genus Cycliocyrillium in which test walls curve orally toward each other and form a a narrow, slightly thickened collar or proceed parallel as a short uncurved neck, not exceeding one-tenth total specimen length, which terminates at the apertural edge.

Description.-Specimens from the Urucum Formation have pyriform tests $(\mathrm{L}=53-113 \mu \mathrm{m}, \quad x=78 \mu \mathrm{m} ; \quad \sigma=27 \mu \mathrm{m}$; $\mathrm{W}=40-84 \mu \mathrm{m}, x=58 \mu \mathrm{m}, \sigma=19 \mu \mathrm{m})$ with a short neck (NL $=2-10 \mu \mathrm{m}, x=6 \mu \mathrm{m}, \sigma=3 \mu \mathrm{m}$ ), terminating in a circular aperture $(\mathrm{AD}=12-34 \mu \mathrm{m}, x=21 \mu \mathrm{m}, \sigma=10 \mu \mathrm{m})$. Aspect ratios $(\mathrm{L} / \mathrm{W})$ range from 1.2 to $1.5(x=1.3 ; \sigma=0.09)$. Walls carbonaceous or siliceous, of uniform thickness (WT $=4-7 \mu \mathrm{m}$, $x=5.3 \mu \mathrm{m}, \sigma=1.3 \mu \mathrm{m})$.

Remarks.-All Urucum specimens of $C$. torquata exhibit short necks rather than collars.

Genus Palaeoamphora Morais, Fairchild, and Lahr, new genus

Type species.—Palaeoamphora urucumense $\mathrm{n}$. gen. n. sp., by monotypy.

Diagnosis.—As for type species, by monotypy.

Etymology.-From palaeo, Greek, ancient; and amphora, Latin, a type of antique Greek vase; with reference to the antiquity and shape of the microfossil.

Remarks.-The funnel-like neck clearly distinguishes Palaeoamphora n. gen. from other taxa having long or short uncurved necks (e.g., Limeta lageniformis n. gen. n. sp. and Cyclocyrillium torquata Porter et al., 2003, respectively).

Palaeoamphora urucumense Morais, Fairchild, and Lahr, new species

Figures 5.3-5.5, 6.4-6.6

2003 Unnamed form Porter et al., p. 423, fig. 17.1-17.3.

Type material. $-\mathrm{N}=6$; Holotype, GP/5T-2534 F (Fig. 6.6). Paratypes (Fig. 6.4, 6.5), GP/5T: 2433 A; 2534 B; 2536 A, B; GP/5T: 2540 A, from the Neoproterozoic Urucum Formation, Jacadigo Group, Corumbá, Brazil (Repository: LPS, IGc-USP).

Diagnosis._VSMs having a pyriform test with a funnel-like neck comprising up to one-sixth the total length of the specimen.

Description.-Total test length (L) $=90-135 \mu \mathrm{m} ; x=115 \mu \mathrm{m}$; $\sigma=17 \mu \mathrm{m} ; \mathrm{W}=60-109 \mu \mathrm{m}, x=83 \mu \mathrm{m}, \sigma=18 \mu \mathrm{m}$. Circular aperture (external aperture diameter, $\mathrm{AD}=37-66 \mu \mathrm{m}$, $x=52 \mu \mathrm{m} ; \sigma=12 \mu \mathrm{m})$ at the terminus of a flaring, funnel-like neck comprising no more than one-sixth total specimen length
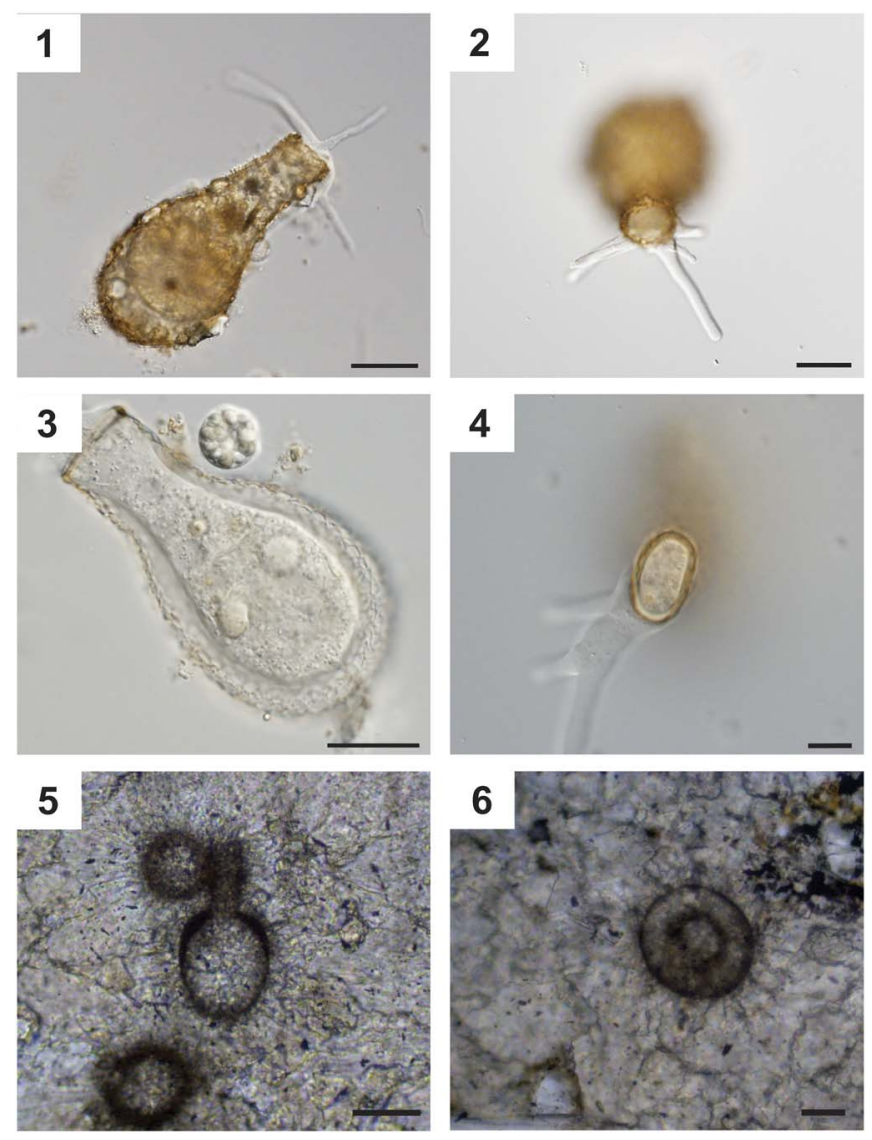

Figure 7. Comparison of modern testate amoebae (1-4) and VSMs from the Neoproterozoic Urucum Formation (Jacadigo Group, Corumbá, Brazil) $(\mathbf{5}, \mathbf{6})$. (1, 2) Longitudinal (1) and transverse (2) views of modern Difflugia (images: D.J.G. Lahr); (3, 4) longitudinal (3) and transverse (4) views of modern Padaungiella (images, D.J.G. Lahr); (5, 6) longitudinal (5) and transverse (6) views of paratypes of Limeta lageniformis n. gen. n. sp. with shape similar to Difflugia (GP/5T-2536 C, B, respectively). Scale bars $=20 \mu \mathrm{m}(\mathbf{1}, \mathbf{2}), 37.5 \mu \mathrm{m}(\mathbf{3}), 17.5 \mu \mathrm{m}(\mathbf{4}), 50 \mu \mathrm{m}$ (5), or $20 \mu \mathrm{m}(\mathbf{6})$.

$(\mathrm{NL}=11-19 \mu \mathrm{m}, x=15 \mu \mathrm{m} ; \sigma=3.2 \mu \mathrm{m})$. Body length (L minus NL $=$ BL $), 78-124 \mu \mathrm{m}(x=99 \mu \mathrm{m} ; \sigma=17.5 \mu \mathrm{m})$. Total specimen aspect ratios $(\mathrm{L} / \mathrm{W}) 1.2-1.7(x=1.4 ; \sigma=0.17)$; body aspect ratios $(\mathrm{BL} / \mathrm{W}) 1.1-1.4(x=1.22 \mu \mathrm{m} ; \sigma=0.13 \mu \mathrm{m})$. Walls carbonaceous, of uniform thickness (WT $=5-6 \mu \mathrm{m}$; $x=5.3 \mu \mathrm{m} ; \sigma=0.57 \mu \mathrm{m})$.

Etymology.-After the Urucum Formation, in which it was found.

Remarks.-Porter et al. (2003, fig. 17.1-17.3) previously distinguished an "unnamed form" in the Chuar Group, consisting of siliceous casts of three incomplete specimens with partially preserved funnel-like necks. The discovery of seven similar, organically preserved forms with complete necks in the Urucum Formation justifies the erection of this taxon to include all these specimens.

Genus Limeta Morais, Fairchild, and Lahr, new genus

Type species._Limeta lageniformis $\mathrm{n}$. gen. $\mathrm{n}$. sp., by monotypy.

Diagnosis.-As for type species, by monotypy. 
Etymology.—Limeta is Guarani (a major indigenous language in South America) for bottle.

Remarks.-The well-developed neck occupying 20-50\% of the total specimen length differentiates this new genus and species from other formally VSM taxa, particularly Cycliocyrillium torquata Porter et al., 2003, whose neck does not exceed $10 \%$ of total test length.

Limeta lageniformis Morais, Fairchild, and Lahr, new species Figures 4.4, 6.7-6.9, 7.5, 7.6

Type material. $-\mathrm{N}=10$; Holotype GP/5T: $2529 \mathrm{~F}$ (Figs. 4.4, 6.9). Paratypes (Fig. 6.7, 6.8, 7.5, 7.6) GP/5T: 2530 A, D; 2532 E; 2534 D; 2536 B, C, G, K; GP/5T: 2539 A, from the Neoproterozoic Urucum Formation, Jacadigo Group, Corumbá, Brazil (Repository: LPS, IGc-USP).

Diagnosis.-VSMs with tests consisting of a pyriform to subglobose body and a long neck, 20-50\% the total length of the test, with a simple terminal aperture.

Description.-Total test length $(\mathrm{L})=100-133 \mu \mathrm{m} ; x=115 \mu \mathrm{m}$; $\sigma=11 \mu \mathrm{m} . \mathrm{W}=53-70 \mu \mathrm{m}, x=63 \mu \mathrm{m}, \sigma=5.6 \mu \mathrm{m}$. Circular aperture ( $\mathrm{AD}=12-32 \mu \mathrm{m}, x=21 \mu \mathrm{m} ; \sigma=5 \mu \mathrm{m})$ at the terminus of a long, cylindrical neck (NL $=20-58 \mu \mathrm{m} ; x=40 \mu \mathrm{m}$; $\sigma=13 \mu \mathrm{m})$. Body length $(\mathrm{BL})=56-89 \mu \mathrm{m}$; aspect ratios calculated for total test length (L/W) $1.5-2(x=1.8 ; \sigma=0.17)$, but are considerably less (1.0-1.3) when just the body length $(\mathrm{BL} / \mathrm{W})$ is considered. Walls carbonaceous, uniformly thick (WT $=5-6 \mu \mathrm{m} ; x=5.7 \mu \mathrm{m} ; \sigma=0.58 \mu \mathrm{m}$ ).

Etymology.—Lageniformis, from the Latin, lagena, bottle; and forma, shape.

Remarks.-At least four other long-necked Neoproterozoic microfossils have been illustrated in the paleontological literature, but none qualifies for inclusion in L. lageniformis $\mathrm{n}$. gen. $\mathrm{n}$. sp. Knoll and Calder (1983, pl. 1, fig. 13) drew attention to a "long-necked" VSM in the Ryssö Formation, Svalbard. It is much larger than L. lageniformis $\mathrm{n}$. gen. $\mathrm{n}$. sp. $(\mathrm{L}=260 \mu \mathrm{m})$, but its 'long' neck represents less than $10 \%$ of the total test length $(\mathrm{NL}=19 \mu \mathrm{m})$ and its aspect ratio is much greater (2.6). Xiao et al. (2014, fig. 5B) recently presented a ferrousoxide-lined mold having a neck nearly $60 \%$ the total length of the specimen within an assemblage of "possible vase-shaped microfossils" from the Jiayuan Formation (lower Huaibei Group) of China, of presumptive late Tonian (>716 Ma) age. But it, too, is large, more than twice the length $(\mathrm{L}=320 \mu \mathrm{m})$ of the largest specimen of $L$. lageniformis $n$. gen. $n$. sp. $(\mathrm{L}=133 \mu \mathrm{m}$ ), and has a much squatter body (aspect ratio, $\mathrm{BL} / \mathrm{W} \approx 0.8$ versus $1.0-1.3$ ). Battison and Brasier (2012, fig. 8D) illustrated an unnamed, similarly shaped organic-walled microfossil of smaller size from the Torridon Group ( 1 Ga), Scotland, and pointed out its similarity to the acritarch Germinosphaera bispinosa Butterfield, 1994, described from the Svanbergfjellet Formation (700-750 Ma), Spitsbergen (in Butterfield et al., 1994, fig. 16.D, 16.E, 16.G). Both the single specimen from the Torridon Group $(\mathrm{L}=50 \mu \mathrm{m}$;
$\mathrm{BL}=30 \mu \mathrm{m})$ and $G$. bispinosa $(\mathrm{BL}=13-35 \mu \mathrm{m})$ are much smaller than L. lageniformis $\mathrm{n}$. gen. n. sp. $(\mathrm{BL}=56-89 \mu \mathrm{m})$. Additionally, G. bispinosa may exhibit from one to four extremely long unobstructed processes that are very much narrower $(3-5 \mu \mathrm{m})$ than the neck of L. lageniformis $\mathrm{n}$. gen. $\mathrm{n}$. sp. $(12-32 \mu \mathrm{m})$.

Genus Taruma Morais, Fairchild, and Lahr, new genus

Type species.-Taruma rata $\mathrm{n}$. gen. n. sp., by monotypy.

Diagnosis.—As for type species, by monotypy.

Etymology.-Taruma is Guarani for an olive-shaped fruit; with reference to the shape of the internal chamber in the holotype.

Remarks.-The relatively short cylindrical body, rounded aborally and truncated at the apertural end, distinguishes this taxon from other VSMs.

Taruma rata Morais, Fairchild, and Lahr, new species Figures 4.3, 6.10-6.13, 6.14?

Type material. $-\mathrm{N}=3$; Holotype GP/5T 2533 B (Figs. 4.3, 6.10, 6.11); Paratype GP/5T 2538 A (Fig. 6.12, 6.13); from the Neoproterozoic Urucum Formation, Jacadigo Group, Corumbá, Brazil (Repository: LPS, IGc-USP). The specimen in Figure 6.14 (GP/5T-2536 D) is included in this species, but with reservations, as explained below.

Diagnosis._VSMs with nearly cylindrical test having a rounded aboral end and a flat to low roof-like oral surface with a central narrow circular aperture.

Description.-Holotype (Figs. 4.3, 6.10-6.11) and paratype (Fig. 6.12, 6.13) share the diagnostic characters of the species and are similar in size and aperture diameter, the holotype measuring $94 \mu \mathrm{m}(\mathrm{L})$ by $65 \mu \mathrm{m}$ (W) with an aperture diameter of $21 \mu \mathrm{m}$, and the paratype, $91 \mu \mathrm{m}$ by $73 \mu \mathrm{m}$ with an aperture diameter of $17 \mu \mathrm{m}$, which correspond to aspect ratios of 1.4 and 1.2 , respectively. The oral pole in the holotype is flat and perpendicular to the aboral axis and "roof-like" in the paratype due to the abrupt inward flexure of the walls at an angle of $\sim 45^{\circ}$. The walls of both the holotype and the paratype are siliceous and are uniformly thick in the paratype (WT $=7 \mu \mathrm{m}$ ), but vary in the holotype from $11 \mu \mathrm{m}$ at the aboral pole to $3 \mu \mathrm{m}$ at midsection, thickening rapidly around the ellipsoidal internal cavity at the oral pole to $21 \mu \mathrm{m}$ as measured in the apertural plane.

In the holotype, EDS and Raman spectroscopy confirm the presence of a thin organic coating on the inner side of the siliceous wall. The light brown pigment that colors the palimpsest fibrous texture lining the interior of the paratype (Fig. 6.12) may also be carbonaceous.

Etymology.-Rata from rátã, Guarani for hard; with reference to the reinforced aspect of the oral region in the holotype.

Remarks.-The two specimens assigned to Taruma rata n. gen. n. sp. conform precisely to the species diagnosis and differ from 
all previously described VSM species in these characteristics, thereby justifying the erection of the species. The walls in both are siliceous, which may represent secondary replacement, although, as discussed in the next section, biomineralization might better explain some petrographic features of the walls. Also, the walls thicken (holotype) or bend abruptly inward (paratype) at the oral pole greatly restricting the aperture. The shape and slight thickening of the wall at the oral pole of a third specimen (Fig. 6.14) are reminiscent of the holotype. However, this specimen differs from the type material in several ways. It is smaller $(\mathrm{L}=70.0 \mu \mathrm{m} ; \mathrm{W}=56.1 \mu \mathrm{m})$, the oral surface is less well defined, the aperture much larger $(27.7 \mu \mathrm{m})$, and the wall is kerogenous and much thinner (WT $=3.6 \mu \mathrm{m})$, especially as measured in the apertural plane $(6.5 \mu \mathrm{m})$. Thus, the specimen is attributed to Taruma rata $\mathrm{n}$. gen. $\mathrm{n}$. sp. with reservations in the expectation that future finds will clarify its situation.

\section{Unnamed Form \\ Figure 6.15, 6.16}

Remarks.-Among the Urucum VSMs studied in detail are six pairs of contiguous or nearly contiguous globose tests of unequal size, each between 50 and $100 \mu \mathrm{m}$ in diameter. All six pairs of tests (or "doublets") have carbonaceous walls, but silica is associated with two pairs, including the pair shown in Figure 6.15 and 6.16. This and four other pairs exhibit vestiges of specimen-encompassing isopachous fringing cement.

Doublets are formed in many extant testate amoebae and other protists (e.g., tintinnids) during asexual binary fission. Construction of the daughter tests initiates at the aperture of the parent cell and the two cells/tests remain attached until cytokinesis is complete (Tappan, 1993). From the $\sim 770-740$ Ma old Uinta Mountain Group of Utah, Porter et al. (2003) illustrated a VSM doublet of claviform tests joined at their apertures (p. 410, fig. 2.1) that appears to represent just this process. Preliminary three-dimensional CLSM imaging suggests that the Urucum doublets may be similarly joined, but the evidence is inconclusive.

\section{Affinities of Urucum VSMs and the question of silica biomineralization}

Affinities.-It is now consensus that most VSMs represent testate amoebae (Schopf, 1992; Porter and Knoll, 2000; Porter et al., 2003) having affinities to amoebozoan arcellinids and, less commonly, to euglyphids of the Rhizaria. For example, Porter et al. (2003, fig. 17.1-17.3) illustrated unnamed VSMs having a funnel-like neck from the Chuar Group that they compared to the modern arcellinid Microamphora pontica Valkanov, 1970, although the possibility that these specimens might represent fragmented doublets of a Cycliocyrillium species was also considered. The discovery of similar Urucum specimens that exhibit complete necks supports the comparison with arcellinids such as $M$. pontica and the inclusion both of damaged and complete forms within a distinct taxon, here designated Palaeoamphora urucumense n. gen. n. sp.

Another Urucum VSM, Limeta lageniformis n. gen. n. sp., similarly invites comparison with arcellinids, specifically with Quaternary testate amoebae such as Difflugia gassowski
(Gassowsky, 1936), the long necks (Fig. 7.1, 7.2) of which comprise about a third of the total body length (Ogden and Ellison, 1988). However, modern Difflugia has an agglutinated rather than an organic test like that of L. lageniformis $n$. gen. $n$. sp. Other possible analogues among the arcellinids occur within the hyalosphenid genus Padaungiella Kosakyan et al., 2012, but the necks of such taxa are comparatively short and laterally compressed (Fig. 7.3, 7.4) rather than being long and cylindrical as in L. lageniformis n. gen. n. sp. (Fig. 7.5, 7.6).

Urucum VSMs are also morphologically similar to foraminifera, rhizarian protistans (Fig. 1). In particular, the shapes of the two species of Cycliocyrillium and of L. lageniformis n. gen. n. sp. resemble, respectively, the Paleozoic calcareous foraminifers Eolagena minuta Lipina, 1959 (cf., Loeblich and Tappan, 1964, p. C322, fig. 232, parts 5-7), and the internal cavity of the globular proloculus and undivided tubular chamber of Syzrania bella Reytlinger, 1950 (cf., Loeblich and Tappan, 1988, p. 109, pl. 430.1; Fig. 6.8). Such similarities, however, may merely represent evolutionary convergence of body form among morphologically simple protistans, given that the possible affinity of organic-walled VSMs and thick-walled calcitic foraminifera is as yet unsubstantiated.

A strong case for the affinity of the Chuar Goup VSM Melicerion poikilon Porter et al., 2003 to alveolate euglyphids has been put forward by Porter et al. (2003) who compared the regular pattern of holes present in numerous fossil tests to the points of insertion of siliceous scales in the organic test of modern euglyphids. No isolated siliceous scales were reported.

Wall composition.-A particularly notable feature of the Urucum VSMs that sets them apart from most other occurrences of VSMs is that the walls are preserved in practically all of the tests. Although the great majority of the Urucum specimens have thin carbonaceous (kerogenous) walls, silica is an important wall component in others. Raman spectroscopy has demonstrated that the wall of the specimen of Cycliocyrillium simplex Porter et al., 2003, shown in Figure 5.6-5.8 is a mixture of kerogen and silica. Petrographic microscopy shows that the walls of the specimen of Cycliocyrillium torquata Porter et al., 2003, shown in Figure 6.2 and 6.3, as well as the holotype and paratype of Taruma rata n. gen. n. sp. (Fig. 6.10-6.13) are siliceous. Silica is also a wall component of the unnamed "doublet" of tests shown in Figure 6.15 and 6.16, an occurrence that raises the interesting question of whether such silica represents secondary replacement or might instead evince primary siliceous biomineralization in early protistans.

Biological use of silica is a major factor that controls the present-day global silica cycle and occurs in diverse extant groups, including protists (e.g., diatoms, ciliates, and testate amoebae), metazoans (viz., sponges), and plants, such as horsetails (Equisetum) and grasses (cf., Hodson et al., 2005; Cornelis et al., 2013; Lahr et al., 2015). Throughout most of the Precambrian, prior to the emergence of silica utilization by eukaryotes (Knoll, 2014), continental erosion provided large amounts of silica to the marine environment (Sarmiento, 2013), as evidenced by the abundance of such abiotically precipitated siliceous rocks as banded iron formations and, of particular paleontologic importance, by the abundance of chert-permineralized microbiotas in Precambrian 
carbonate paleoenvironments (Maliva et al., 1989; Siever, 1992; Knoll, 2000). Thus, dissolved silica was evidently available throughout early Earth history for its eventual use by early protistans.

Indeed, members of the Arcellinida and Euglyphida are among the most abundant silica-using protistans in present-day ecosystems (Cary et al., 2005; Wilkinson and Mitchell, 2010; Puppe et al., 2014; Lahr et al., 2015). Modern arcellinids exhibit three processes for the incorporation of silica into their tests: (1) by ingesting grains of quartz and/or phyllosilicates and agglutinating them into their tests, a mechanism characteristic of Diffugia Leclerc, 1815 (Châtelet et al., 2013); (2) via biomineralization of amorphous silica into test-encompassing scales, such as occurs in Quadrulella (Kosakyan et al., 2012); and (3) by kleptosquamy, in which siliceous scales previously produced by other testate amoebae are acquired by predation and reutilized (Lahr et al., 2015). Euglyphids are capable of depositing amorphous silica on their cellular membranes (Puppe et al., 2014). Although the oldest unambiguous fossils of this group date from the Paleogene, some 30-50 Ma ago (Barber et al., 2013), it is pertinent to note that Porter et al. (2003) interpreted the $\sim 742$ Ma old Chuar VSM Melicerion poikilon Porter, Meisterfeld, and Knoll, 2003, as possibly a siliceous-scaled euglyphid. Given these data, it seems plausible that silica biomineralization may have occurred in protistan lineages at least as early as the late Tonian of the Neoproterozoic when the Chuar Group VSMs were preserved.

Secondary replacement is an alternative interpretation to biomineralization as the process responsible for the presence of silica in the walls of the Urucum VSMs. Intrinsic controls on siliceous replacement of such walls include their original composition, the concentration of organic matter within them, and the skeletal ultrastructure of the fossil. Among the external controls of such silicification are the availability of silica, the chemistry of the depositional and/or early diagenetic setting and permeating pore-waters, and post-depositional diagenetic changes of the texture and composition of the fossil-hosting rocks (Butts, 2014). Secondary silicification of microfossils involves partial to complete replacement of the material making up the original structural components, which in the case of VSMs would be their original test walls. For calcareous skeletal elements, this process consists of dissolution of calcium carbonate and subsequent precipitation of silica, promoted by the differing pH-related solubilities of $\mathrm{CaCO}_{3}$ and $\mathrm{SiO}_{2}$ and the propensity of dissolved silica to nucleate on degraded organic matter (Butts and Briggs, 2011; Butts, 2014). Primary features of walls are generally better preserved if they are permineralized in cryptocrystalline to microcrystalline quartz, as commonly occurs during early diagenetic silicification (cf., Calça and Fairchild, 2012) rather than by mold-filling mosaics of megaquartz, as commonly occurs during late-diagenetic replacement (Butts and Briggs, 2011).

Did the Urucum VSMs exhibit original silica biomineralization or were they secondarily replaced? A detailed petrographic study of the VSMs is underway, but a few preliminary petrographic observations regarding the Urucum siliceous-walled specimens and the doublet (the "Unnamed form") shown in Figure 6 are pertinent. First, silica in the doublet (Fig. 6.15, 6.16) appears more likely to have partially filled rather than to have replaced the test at the right of the specimen and to cut the test at its left, which is consistent with secondary silicification. Second, the entirely siliceous wall of Cycliocyrillium torquata Porter et al., 2003 (Fig. 6.2, 6.3) consists of a single quartz crystal (apparently exhibiting undulatory extinction) and lacks preserved relict wall substructure, which is an observation similarly consistent with secondary silicification. Third, the walls of the type specimen of Taruma rata n. gen. n. sp. (Fig. 6.10-6.13) also consist of quartz as in that of $C$. torquata, although the size of the quartz crystals is difficult to discern. Authigenic quartz is present within the same fields of view for both the holotype (Fig. 6.11) and the paratype (Fig. 6.13) of $T$. rata n. gen. n. sp., indicating that siliceous replacement of carbonate and other minerals locally affected the dolostone matrix.

Based on these observations, secondary replacement by quartz of the originally organic walls of the Urucum VSMs seems plausible. However, because only a small minority of the Urucum VSMs has siliceous walls and because such specimens are limited to three of the five taxa here described (two species of Cycliocyrillium Porter, Meisterfeld, and Knoll, 2003 and Taruma rata n. gen. n. sp.) and the unnamed doublets, it would appear secondary silicification was not a selective process.

Nevertheless, secondary silicification is not an entirely satisfactory explanation for all Urucum specimens. For example, were this to have occurred for Cycliocyrillium torquata Porter et al., 2003 (Fig. 6.2, 6.3), silica-substitution would have to have been a substrate-specific process that affected only the original wall of the tests without distorting or disrupting them or altering the adjacent carbonate, including the delicate early diagenetic cement that coats the original wall both inside and out. In this regard, it is significant that the holotype of Taruma rata $\mathrm{n}$. gen. n. sp, (Fig. 6.10) is encased by an external coating of mosaic dolomite substituting an early diagenetic cement. The thin carbonaceous film that coats the inner side of its wall, evidently delimiting the ellipsoidal internal chamber of the test, quite plausibly represents a relict of the originally carbonaceous wall internal to an originally inorganic thick outer wall that was preferentially replaced by quartz (Figs. 5.7, 6.11). The paratype of this taxon is surrounded by mosaic dolomite, but exhibits a clearly defined internal rind of fibrous carbonate (Fig. 6.12, 6.13) that, as in C. torquata (Fig. 6.2), was not disrupted when its wall was presumably replaced by quartz.

Although much evidence points to secondary siliceous replacement of the original organic walls of Urucum VSMs, the foregoing considerations raise two fundamental questions: (1) what was the original composition of the replaced walls, and (2) how were they replaced without altering delicate features in their immediate vicinity?

As an example, what might have been the original composition of the robust walls of Taruma rata $\mathrm{n}$. gen. n. sp.? The simplest explanation would be that like nearly all other Urucum VSMs, they too were originally carbonaceous. If so, their voluminous walls would have offered many more sites for silica nucleation (Maliva and Siever, 1988) than the thinnerwalled VSMs, resulting in their preferential silicification. However, it is also possible that the thick walls of $T$. rata n. gen. n. sp. were originally a mixture of organic matter and silica, as is shown in Figure 5.6-5.8 for a specimen of C. simplex 
Porter, Meisterfeld, and Knoll, 2003. Were this the case, secondary siliceous replacement might have been favored both by the quantity of degraded organic matter in the thick walls, as suggested above, and by the additional sites for silica nucleation afforded by the fine-grained silica present within the walls. This possibility would require that the silica in the mixed carbonaceous-siliceous wall be primary in origin rather than a product of secondary replacement.

Although it seems unlikely, it is also possible that the thick wall of Taruma rata $\mathrm{n}$. gen. $\mathrm{n}$. sp. was originally inorganic, perhaps being calcareous or composed of cryptocrystalline chalcedony or amorphous opaline silica. If originally calcareous, the wall as preserved would have to have been subsequently replaced by quartz. However, if originally composed of very fine-grained silica, the preserved wall would more likely have been recrystallized rather than silica-replaced, a mode of preservation that might explain how it attained its quartzose composition without alteration of its shape and thickness or dissolution of its encompassing dolomitized rind of early diagenetic fibrous cement. Interestingly, both these possibilities would require the occurrence of biomineralization, for which at present there is no definitive evidence. It nevertheless remains conceivable that further detailed study of the siliceous walls of Taruma rata (e.g., Fig. 6.11, 6.13) might reveal textural evidence, such as the occurrence of carbonate inclusions or relict ultrastructure, indicative of biomineralization that, were it to be substantiated, would be unlikely to have resulted from either silica-agglutination or kleptosquamy, processes that both give rise to irregular test surfaces (Fig. 7.1).

A final question to be considered is "why are organic walls preserved in almost all Urucum VSMs when they are so rarely known in other occurrences of VSMs?" On the basis of the evidence available, we suggest that the answer lies in their encasement during very early diagenesis by a rind of isopachous carbonate cement, which we interpret to have been fundamental to impeding significant subsequent diagenetic degradation (cf., Butts and Briggs, 2011).

\section{Conclusions}

Vase-shaped microfossils of the Neoproterozoic Urucum Formation (Jacadigo Group, west-central Brazil) are diverse and exhibit well-preserved walls, providing insight into the biological affinity and evolutionary status of this evidently early originating group of protozoans. Fibrous carbonate cement entombed the tests during early diagenesis, conserving their shape and preserving evidence of their original organic and organo-siliceous compositions. Secondary silica evidently replaced some tests, the occurrence of which does not exclude the possibility of some Urucum VSMs being originally biomineralized. In conjunction with previously described VSMs, the Urucum specimens substantiate the global distribution, early diversification, and abundance of arcellinid testate amoebae in Neoproterozoic oceans.

\section{Acknowledgments}

A doctoral scholarship provided by FAPESP (Proc. 2013/12852-1) supported L.M.; A.K.G. was supported by a UCLA-Eugene V. Cota-Robles Fellowship and CSEOL (the UCLA Center for the Study of Evolution and the Origin of Life); D.J.G.L. is supported by FAPESP (Proc. 2013/04585-3); and A.B.K., by CSEOL and WARC (the University of Wisconsin Astrobiology Research Consortium). The authors also thank M.F. Zaine, C. Simonetti, and P.C. Boggiani who participated in earlier research on these fossils, the Journal's reviewers, S. Porter (University of California, Santa Barbara [UCSB]) and M. Marti Mus (Universidad de Extremadura, Spain), and editor M. Moczydłowska-Vidal, for useful suggestions.

\section{References}

Allison, C.W., and Awramik, S.M., 1989, Organic-walled microfossils from earliest Cambrian or latest Proterozoic Tindir Group rocks, northwest Canada: Precambrian Research, v. 43, p. 253-224.

Almeida, F.F.M., 1964, Glaciação eocambriana em Mato Grosso: Boletim da Divisão de Geologia e Mineralogia, Departamento Nacional de Produção Mineral, v. 117, p. 1-11. [in Portuguese]

Anderson, R.P., Fairchild, I.J., Tosca, N.J., and Knoll, A.H., 2013, Microstructures in metasedimentary rocks from the Neoproterozoic Bonahaven Formation, Scotland: Microconcretions, impact spherules, or microfossils?: Precambrian Research, v. 233, p. 59-72.

Angerer, T., Hagemann, S.G., Walde, D., Halverson, G.P., and Boyce, A.J., 2016 Multiple metal sources in the glaciomarine facies of the Neoproterozoic Jacadigo iron formation in the "Santa Cruz deposit", Corumbá, Brazil: Precambrian Research, v. 275, p. 369-393.

Babinski, M., Boggiani, P.C., Trindade, R.I.F., and Fanning, C.M., 2013, Detrital zircon ages and geochronological constraints on the Neoproterozoic Puga diamictites and associated BIFs in the southern Paraguay Belt, Brazil: Gondwana Research, v. 23, p. 988-997.

Barber, A., Siver, P.A., and Karis, W., 2013, Euglyphid testate amoebae (Rhizaria: Euglyphida) from an Arctic Eocene waterbody: evidence of evolutionary stasis in plate morphology for over 40 million years: Protist, v. 164, p. 541-555.

Barbosa, O., 1949, Contribuição à geologia da região Brasil-Bolivia: Mineração e Metalurgia, v. 13, p. 271-278. [in Portuguese]

Battison, L., and Brasier, M.D., 2012, Remarkably preserved prokaryote and eukaryote microfossils within 1 Ga-old lake phosphates of the Torridon Group, NW Scotland: Precambrian Research, v. 196, p. 204-217.

Binda, P.L., and Bokhari, M.M., 1980, Chitinozoanlike microfossils in a late Precambrian dolostone from Saudi Arabia: Geology, v. 8, p. 70-71.

Bloeser, B., 1985, Melanocyrillium, a new genus of structurally complex late Proterozoic microfossils from the Kwagunt Formation (Chuar Group), Grand Canyon, Arizona: Journal of Paleontology, v. 59, p. 741-765.

Bloeser, B., Schopf, J.W., Horodyski, R.J., and Breed, W.J., 1977, Chitinozoans from the Late Precambrian Chuar Group of the Grand Canyon, Arizona: Science, v. 195 , p. 676-679.

Boggiani, P.C., 2010, Sedimentação autigênica Neoproterozóica e mineralizações associadas - um registro não uniformitarista [Docent dissertation]: São Paulo, Universidade de São Paulo, 136 p. [in Portuguese]

Boggiani, P.C., and Coimbra, A.M., 2002, Morraria do Puga, MS-Típica associação neoproterozoica de glaciação e sedimentação carbonática, in Schobbenhaus, C., Campos, D.A., Queiroz, E.T., Winge, M., and Berbert-Born, M.L.C., eds., Sítios Geológicos e Paleontológicos do Brasil: DNPM/CPRM - Comissão Brasileira de Sítios Geológicos e Paleobiológicos (SIGEP), v. 1, p. 195-201. [in Portuguese] http://sigep.cprm.gov.br/sitio037/ sitio037.htm

Boggiani, P.C., Ferreira, V.P., Sial, A.N., Babinski, M., Trindade, R.I.F., Aceñolaza, G., and Parada, M.A., 2003, The cap carbonate of the Puga Hill (Central South America) in the context of the post-Varanger Glaciation: Fourth South American Symposium on Isotope Geology, Salvador, Brazil, 2003, Abstracts.

Bosak, T., Lahr, D.J.G., Pruss, S.B., Macdonald, F.A., Dalton, L., and Matys, E., 2011, Agglutinated tests in post-Sturtian cap carbonates of Namibia and Mongolia: Earth and Planetary Science Letters, v. 308, p. 29-40.

Bosak, T., Lahr, D.J., Pruss, S.B., Macdonald, F.A., Gooday, A.J., Dalton, L., and Matys, E.D., 2012, Possible early foraminiferans in post-Sturtian (716-635 Ma) cap carbonates: Geology, v. 40, p. 67-70.

Butts, S.H., 2014, Silicification, in Laflamme, M., Schiffbauer J.D., Darroch S A.F., eds., Reading and Writing of the Fossil Record: Preservational Pathways to Exceptional Fossilization: The Paleontological Society Papers, v. 20 , p. $15-33$.

Butts, S.H., and Briggs, D.E.G., 2011, Silicification through time, in Allison A., and Bottjer D., eds., Taphonomy, Second Edition-Process and Bias Through Time: Dordrecht, Netherlands, Springer, p. 411-434.

Butterfield, N.J., 2015, Early evolution of the Eukarya: Palaeontology, v. 58, p. 5-17. 
Butterfield, N.J., Knoll, A.H., and Swett, K., 1994, Paleobiology of the Neoproterozoic Svanbergfjellet Formation, Spitsbergen: Fossils and Strata, v. 34 , p. $1-84$

Calça, C.P., and Fairchild, T.R., 2012, Petrographic approach to the study of organic microfossils from the Irati Subgroup (Permian, Parana Basin, Brazil): Journal of South American Earth Sciences, v. 35, p. 51-61.

Cary, L., Alexandre, A., Meunier, J.D., Boeglin, J. L., and Braun, J.J., 2005, Contribution of phytoliths to the suspended load of biogenic silica in the Nyong basin rivers (Cameroon): Biogeochemistry, v. 74, p. 101-114.

Châtelet, E.A., Noiriel, C., and Delaine, M., 2013, Three-dimensional morphological and mineralogical characterization of testate Amoebae: Microscopy and Microanalysis, v. 19, p. 1511-1522.

Cohen, K.M., Finney, S.C., Gibbard, P.L., and Fan, J.X., 2013, The ICS international chronostratigraphic chart: Episodes, v. 36, 199-204.

Cornelis, J.T., Delvaux, B., Georg, R.B., Lucas, Y., Ranger, J., and Opfergelt, S., 2013, Tracing the origin of dissolved silicon transferred from various soil-plant systems towards rivers: a review: Biogeosciences, v. 8 , p. 89-112.

Corsetti, F. A., Awramik, S. M., and Pierce, D., 2003, A complex microbiota from snowball Earth times: microfossils from the Neoproterozoic Kingston Peak Formation, Death Valley, USA: Proceedings of the National Academy of Sciences, v. 100, p. 4399-4404.

Dalton, L.A., Bosak, T., Macdonald, F.A., Lahr, D.J., and Pruss, S.B., 2013, Preservational and morphological variability of assemblages of agglutinated eukaryotes in Cryogenian cap carbonates of northern Namibia: Palaios, v. 28 , p. $67-79$.

Dehler, C.M., Fanning, C.M., Link, P.K., Kingsbury, E.M., and Rybczynski, D., 2010, Maximum depositional age and provenance of the Uinta Mountain Group and Big Cottonwood Formation, northern Utah: paleogeography of rifting western Laurentia: Geological Society of America Bulletin, v. 122 , p. $1686-1699$.

Ding, L., Zhang, L., Li, Y., and Dong, J., 1992, The Study of the Late Sinian-Early Cambrian Biotas from the Northern Margin of the Yangtze Platform: Beijing, Scientific and Technical Documents Publishing House, $135 \mathrm{p}$.

Dorr, J.V.N., 1945, Manganese and iron deposits of Morro do Urucum, Mato Grosso, Brazil: Bulletin of the United States Geological Survey 946A, $47 \mathrm{p}$.

Dorr, J. V. N., 1973, Iron-formation in South America: Economic Geology, v. 68 , p. $1005-1022$.

Duan, C., 1985, The earliest Cambrian vase-shaped microfossils of Fangxian County, Hubei Province: Bulletin of the Tianjin Institute of Geology and Mineral Resources, v. 13, p. 87-107.

Duan, C., Cao, F., and Zhang, L., 1993, Vase-shaped microfossils from top of the Tongying Formation in Xixiang, Shaanxi: Acta Micropalaeontologica Sinica, v. 10, 397-408.

Ewetz, C.E., 1933, Einige neue Fossilfunde in der Visingsöformation: Geologiska Föreningen i Stockholm Förhandlingar (GFF), v. 55, p. 506-518.

Fairchild, T.R., Barbour, A.P., and Haralyi, N.L., 1978, Microfossils in the "Eopaleozoic" Jacadigo Group at Urucum, Mato Grosso, Southwest Brazil: Boletim IG-USP, v. 9, p. 74-78.

Fiz-Palacios, O., Leander, B.S., and Heger, T.J., 2014, Old lineages in a new ecosystem: diversification of Arcellinid Amoebae (Amoebozoa) and peatland mosses: PLOS One, 9:e95238.

Folk, R.L., 1987, Detection of organic matter in thin-sections of carbonate rocks using a white card: Sedimentary Geology, v. 54, p. 193-200.

Freitas, B.T., Warren, L.V., Boggiani, P.C., De Almeida, R.P., and Piacentini, T., 2011, Tectono-sedimentary evolution of the Neoproterozoic BIF-bearing Jacadigo Group, SW-Brazil: Sedimentary Geology, v. 238, p. 48-70.

Gassowsky, G.N., 1936, Nove Rhizopoda iz ozer Konchezerskoi grupp (v Karelii) - (French summary: Quelques Rhizopodes nouveaux des lacs du group de Kontchesero [en Karélie]): Trudy Borodinskoi Biologicheskoi Stantsii/Berichte der Biologischen Borodin Station, v. 8, p. $101-121$.

Green, J.W., Knoll, A.H., and Swett, K, 1988, Microfossils from oolites and pisolites of the Upper Proterozoic Eleonore Bay Group, central east Greenland: Journal of Paleontology, v. 62, p. 835-852.

Hasui, Y., and Almeida, F.D., 1970, Geocronologia do centro-oeste brasileiro: Boletim da Sociedade Brasilerira de Gelogia, v. 19, p. 5-26. [in Portuguese]

Hodson, M.J., White, P.J., Mead, A., and Broadley, M.R., 2005, Phylogenetic variation in the silicone composition of plants: Annals of Botany, v. 96 , p. $1027-1046$

Hoffman, P.F., and Schrag, D.P., 2002, The snowball Earth hypothesis: testing the limits of global change: Terra Nova, v. 14, p. 129-155.

Hoffman, P.F., Kaufman, A.J., Halverson, G.P., and Schrag, D.P., 1998, A Neoproterozoic snowball earth: Science, v. 281, p. 1342-1346.

Horodyski, R.J., 1993, Paleontology of Proterozoic shales and mudstones: examples from the Belt Supergroup, Chuar Group and Pahrump Group, western USA: Precambrian Research, v. 61, p. 241-278.
Karlstrom, K.E., Bowring, S.A., Dehler, C.M., Knoll, A.H., Porter, S.M., Des Marais, D.J., Weil, A.B., Sharp, Z.D., Geissman, J.W., Elrick, M.B., Timmons, M.J., Crossey, L.J., and Davidek, K.L., 2000, Chuar Group of the Grand Canyon: record of breakup of Rodinia, associated change in the global carbon cycle, and ecosystem expansion by 740 Ma: Geology, v. 28, p. 619-622.

Knoll, A.H., 2000, Learning to tell Neoproterozoic time: Precambrian Research, v. 100 , p. $3-20$

Knoll, A.H., 2014, Paleobiological perspectives on early eukaryotic evolution: Cold Spring Harbor Perspectives in Biology, v. 6, p. 1-14.

Knoll, A.H., and Calder, S., 1983, Microbiotas of the Late Precambrian Ryssö Formation, Nordaustlandet, Svalbard: Palaeontology, v. 26, p. 467-496.

Knoll, A.H., and Vidal, G, 1980, Late Proterozoic vase-shaped microfossils from the Visingsö Beds, Sweden: Geologiska Föreningen I Stockholm Förhandlingar, v. 102, 207-211.

Knoll, A.H., Swett, K., and Burkhardt, E., 1989, Paleoenvironmental distribution of microfossils and stromatolites in the Upper Proterozoic Backlundtoppen Formation, Spitsbergen: Journal of Paleontology, v. 63, p. 129-145.

Knoll, A.H., Swett, K., and Mark, J., 1991, Paleobiology of a Neoproterozoic tidal flat/lagoonal complex: the Draken Conglomerate Formation, Spitsbergen: Journal of Paleontology, v. 65, p. 531-570.

Kosakyan, A., Heger, T.J., Leander, B.S., Todorov, M., Mitchell, E.A., and Lara, E., 2012, COI barcoding of Nebelid testate amoebae (Amoebozoa: Arcellinida): extensive cryptic diversity and redefinition of the Hyalospheniidae Schultze: Protist, v. 163, p. 415-434.

Lahr, D.J., Bosak, T., Lara, E., and Mitchell, E.A., 2015, The Phanerozoic diversification of silica-cycling testate amoebae and its possible links to changes in terrestrial ecosystems: PeerJ, 3:e1234. https://doi.org/10.7717/ peerj. 1234

Leclerc, M., 1815, Note sur la Difflugie, nouveau genre de Polype amorph: Mémories du Muséum d'Histoire Naturelle (Paris), v. 2, p. 474-478.

Leeuwen, P.V., and Graf, J.L., 1987, The Urucum-Mutun iron and manganese deposits, Mato Grosso do Sul, Brazil and Sta. Cruz, Bolivia. Part II. Stratigraphy, lithology and origin: Geologie en Mijnbouw, v. 65, p. 327-343.

Lipina, O.A., 1959, A find of foraminifera in the Silurian and Ordovician layers Siberia: Doklady Akademii Nauk SSSR, v. 128, p. 823-826. (in Russian)

Li, Y., Guo, J., Zhang, X., Zhang, W., Liu, Y., Yang, W., Li, Y., Liu, L., and Shu, D., 2008, Vase-shaped microfossils from the Ediacaran Weng'an biota, Guizhou, South China: Gondwana Research, v. 14, p. 263-268.

Litherland, M., and Bloomfield, K., 1981, The Proterozoic history of eastern Bolivia: Precambrian Research, v. 15, p. 157-179.

Litherland, M., Annells, R.N., Appleton, J.D., Berrangé, J.P., Bloomfield, K., Burton, C.C.J., Darbyshire, D.P.F., Fletcher, C.J.N., Hawkins, M.P., Klinck, B. A., Llanos, A., Mitchell, W.I., O'Connor, E.A., Pitfield, P.E.J., Power, G., and Webb, B.C., 1986, The geology and mineral resources of the Bolivian Precambrian shield: British Geological Survey, Overseas Memoir, v. 9, 153 p.

Loeblich, A.R., Jr., and Tappan, H., 1964, Treatise on Invertebrate Paleontology. Part C. Sarcodina, chiefly "Thecamoebans" and Formainiferida: Boulder, $\mathrm{CO}$ and Lawrence, KS, The Geological Society of America and the University of Kansas, v. 1, $510 \mathrm{p}$

Loeblich, A.R., Jr., and Tappan, H., 1988, Foraminiferal Genera and their Classification: New York, Van Nostrand Reinhold Co., Inc., v. 1, 970 p., v. 2, 212 p., $847 \mathrm{pl}$.

Macdonald, F.A., Halverson, G.P., Strauss, J.V., Smith, E.F., Cox, G., Sperling, E.A., and Roots, C.F., 2010, Early Neoproterozoic Basin Formation in Yukon, Canada: Implications for the make-up and break-up of Rodinia: Geoscience Canada, v. 39, p. 77-100.

Maciel, P., 1959, Tilito Cambriano (?) no Estado de Mato Grosso: Boletim da Sociedade Brasileira de Geologia, São Paulo, v. 8, p. 31-39. [in Portuguese]

Maithy, P.K., and Babu, R., 1988, Chitinozoa-like remains from Vindhyan Supergroup of Son Valley: Paleobotanist, v. 37, p. 77-80.

Maliva, R.G., and Siever, R., 1988, Mechanism and controls of silicification of fossils in limestones: Journal of Geology, v. 96, p. 387-398.

Maliva, R.G., Knoll, A.H., and Siever, R., 1989, Secular change in chert distribution: a reflection of evolving biological participation in the silica cycle: Palaios, v. 4, p. 519-532.

Martí Mus, M., and Moczydłowska, M., 2000, Internal morphology and taphonomic history of the Neoproterozoic vase-shaped microfossils from the Visings Group, Sweden: Norsk Geologisk Tidsskrift, v. 80, p. 213-228.

Maslov, A.V., 2004, Riphean and Vendian sedimentary sequences of the Timanides and Uralides, the eastern periphery of the East European Craton: Geological Society, London, Memoirs, v. 30, p. 19-35.

Maslov, A.V., Abduazimova, Z.M., Karsten, L.A., and Puchkov, V.N., 1994, Melanocyrillium forms first found in the Riphean type sections of the Southern Urals, Sostoyanie, problemy i zadacha geologicheskogo kartirovaniya oblastei razvitiya dokembriya na territorii Rossii: Tezisy doklada Vserossiiskoi soveshch (Proceedings of the All-Russia Conference on State of the Art, Problems and Objectives of Geological Survey within the Precambrian Regions of Russia), St. Petersburg: VSEGEI, 90 p. (in Russian) 
Nautiyal, A.C., 1978, Discovery of cyanophycean algal remains and chitinozoans from the Late Precambrian argillaceous sequence of Satpuli, Garhwal Himalaya, India: Current Science, v. 47, p. 222-226.

O'Connor, E.A., and Walde, D.H.G., 1985, Recognition of an Eocambrian Orogenic Cycle in SW Brazil and SE Bolivia: Zentralblatt für Geologie und Paläontologie, v. 9, p. 1441-1456.

Ogden, C.G., and Ellison, R.L., 1988, The value of the organic cement matrix in the identification of the shells of fossil testate amoebae: Journal of Micropalaeontology, v. 7, p. 233-240.

Parfrey, L.W., Lahr, D.J.G., Knoll, A.H., and Katz, L.A., 2011, Estimating the timing of early eukaryotic diversification with multigene molecular clocks: Proceedings of the National Academy of Sciences, USA, v. 108 , p. 13624-13629.

Piacentini, T., Vasconcelos, P.M., and Farley, K.A., 2013, ${ }^{40} \mathrm{Ar} /{ }^{39} \mathrm{Ar}$ constraints on the age and thermal history of the Urucum Neoproterozoic banded iron-formation, Brazil: Precambrian Research, v. 248, p. 48-62.

Porter, S., 2011, The rise of predators: Geology, v. 39, p. 607-608.

Porter, S.M., and Knoll, A.H., 2000, Testate amoebae in the Neoproterozoic Era: evidence from vase-shaped microfossils in the Chuar Group Grand Canyon: Paleobiology, v. 26, p. 360-385.

Porter, S.M., Meisterfeld, R., and Knoll, A.H., 2003, Vase-shaped microfossils from the Neoproterozoic Chuar Group, Grand Canyon: a classification guided by modern testate amoebae: Journal of Paleontology, v. 77, p. 409-429.

Puppe, D., Kaczorek, D., Wanner, M., and Sommer, M., 2014, Dynamics and drivers of the protozoan Si pool along a 10-year chronosequence of initial ecosystem states: Ecological Engineering, v. 70, p. 477-482.

Reytlinger, E.A., 1950, Foraminifera from the Middle Carboniferous deposits of the central part of the Russian Platform (exclusive of the family Fusulinidae): Akademiya Nauk SSSR, Trudy Instituta Geologicheskikh Nauk, vypusk 126, Geologicheskaya Seriya, v. 47, p. 1-127. [in Russian]

Saito, Y., Tiba, T., and Matsubara, S., 1988, Precambrian and Cambrian cherts in northwestern Tasmania: Bulletin of the National Science Museum, Series C, v. 14 , p. $59-70$

Sarmiento, J.L., 2013, Ocean Biogeochemical Dynamics: Princeton, New Jersey, Princeton University Press, $528 \mathrm{p}$.

Schopf, J.W., 1992, Evolution of the Proterozoic biosphere: benchmarks, tempo, and mode, in Schopf, J.W., and Klein, C., eds., The Proterozoic Biosphere, a Multidisciplinary Study: Cambridge, Cambridge University Press, p. 583-600.

Schopf, J.W., Kudryavtsev, A.B., Agresti, D.G., Wdowiak, T.J., and Czaja, A. D., 2002, Laser-Raman imagery of Earth's earliest fossils: Nature, v. 416, p. $73-76$.

Schopf, J.W., Kudryavtsev, A.B., Agresti, D.G., Czaja, A.D., and Wdowiak, T. J., 2005, Raman imagery: a new approach to assess the geochemical maturity and biogenicity of permineralized Precambrian fossils: Astrobiology, v. 5, p. 333-371.

Schopf, J.W., Tripathi, A., and Kudryavtsev, A.B., 2006, Three-dimensional confocal optical microscopy of Precambrian microscopic organisms: Astrobiology, v. 6, p. 1-16

Schopf, J.W., Calça, C.P., Garcia, A.K., Kudryavtsev, A.B., Souza, P.A., Félix, C.M., and Fairchild, T. R., 2016, In situ confocal laser scanning microscopy and Raman spectroscopy of bisaccate pollen from the Irati Subgroup (Permian, Paraná Basin, Brazil): comparison with acidmacerated specimens: Review of Palaeobotany and Palynology, v. 233, p. $169-175$.
Sergeev, V.N., and Schopf, J.W., 2010, Taxonomy, paleoecology and biostratigraphy of the late Neoproterozoic Chichkan microbiota of South Kazakhstan: the marine biosphere on the eve of metazoan radiation: Journal of Paleontology, v. 84, p. 363-401.

Siever, R., 1992, The silica cycle in the Precambrian: Geochimica et Cosmochimica Acta, v. 56, p. 3265-3272.

Strauss, J.V., Rooney, A.D., Macdonald, F.A., Brandon, A.D., and Knoll, A.H., 2014, 740 Ma vase-shaped microfossils from Yukon, Canada: implications for Neoproterozoic chronology and biostratigraphy: Geology, v. 42, p. 659-662.

Tappan, H., 1993, Tintinnids, in Lipps, J.H., ed., Fossil Prokaryotes and Protists: Boston, Blackwell Scientific Publications, p. 285-303.

Tucker, M.E., and Wright, V.P., 1990, Carbonate Sedimentology: Oxford, John Wiley \& Sons, $251 \mathrm{p}$.

Turner, N.J., Black, L.P., and Kamperman, M., 1998, Dating of Neoproterozoic and Cambrian orogenies in Tasmania: Australian Journal of Earth Sciences, v. 45 , p. $789-806$.

Urban, H., Stribrny, B., and Lippolt, H.J., 1992, Iron and manganese deposits of the Urucum district, Mato Grosso do Sul, Brazil: Economic Geology, v. 87, p. $1375-1392$.

Valkanov, A., 1970, Beitrag zur Kenntnis der Protozoen des Schwarzen Meeres: Zoologischer Anzeiger, v. 184, p. 241-290.

Venkatachala, B.S., and Kumar, A., 1998, Fossil microbiota from the Vaishnodevi Limestone, Himalayan Foothills, Jammu: age and palaeoenvironmental implications: Geological Society of India, v. 52, p. 529-536.

Vidal, G., 1979, Acritarchs from the upper Proterozoic and lower Cambrian of East Greenland: Grønlands Geologiske Undersøgelse, v. 134, p. $1-55$.

Vidal, G., and Moczydłowska, M., 1995, The Neoproterozoic of Balticastratigraphy, palaeobiology and general geological evolution: Precambrian Research, v. 73, p. 197-216.

Vidal, G., and Siedlecka, A., 1983, Planktonic, acid-resistant microfossils from the Upper Proterozoic strata of the Barents Sea region of Varanger Peninsula, East Finnmark, northern Norway: Norges Geologiske Undersokelse Bulletin, v. 71, p. 45-79.

Walde, D.H.G., and Oliveira, M.M., 1980, Substratos para a estratigrafia dos grupos Corumbá e Jacadigo na região de Corumbá,MS, in 31st Congresso Brasileiro de Geologia: Balneário de Camburiú, Sociedade Brasileira de Geologia, Resumos, Boletim 2, 446 p. [in Portuguese]

Wilkinson, D.M., and Mitchell, E.A., 2010, Testate amoebae and nutrient cycling with particular reference to soils: Geomicrobiology Journal, v. 27, p. $520-533$.

Xiao, S., Shen, B., Tang, Q., Kaufman, A.J., Yuan, X., Li, J., and Qian, M. 2014, Biostratigraphic and chemostratigraphic constraints on the age of early Neoproterozoic carbonate successions in North China: Precambrian Research, v. 246, p. 208-225.

Zaine, M.F., 1991, Analise dos fósseis de parte da Faixa Paraguai (MS, MT) e seu contexto temporal e paleoambiental. [Ph.D. thesis]: São Paulo, Universidade de São Paulo, 218 p. [in Portuguese with English abstract].

Zhang, L., 1994, A new progress in research on vase-shaped microfossils from the Dengying Formation of Sinian in southern Shaanxi Province: Acta Geologica Gansu, v. 13, p. 1-8.

Zhang, L., and Li, Y., 1991, The Late Sinian vasiform microfossils of Ningqiang, Shaanxi Province: Northwest Geoscience, v. 1, p. 1-5.

Accepted 3 March 2017 